IMF Country Reports $\quad 11 / 261$

Chile: Financial System Stability Assessment

INTERNATIONAL MONETARY FUND 


\title{
Chile: Financial System Stability Assessment
}

This financial system stability assessment on Chile was prepared by a staff team of the International Monetary Fund as background documentation for the periodic consultation with the member country. It is based on the information available at the time it was completed on August 09, 2011. The views expressed in this document are those of the staff team and do not necessarily reflect the views of the government of Chile or the Executive Board of the IMF.

The policy of publication of staff reports and other documents by the IMF allows for the deletion of market-sensitive information.

\author{
Copies of this report are available to the public from \\ International Monetary Fund • Publication Services \\ $70019^{\text {th }}$ Street, N.W. • Washington, D.C. 20431 \\ Telephone: (202) 623-7430 • Telefax: (202) 623-7201 \\ E-mail: publications@imf.org Internet: http://www.imf.org
}

\section{International Monetary Fund Washington, D.C.}


INTERNATIONAL MONETARY FUND

CHILE

Financial System Stability Assessment Update

Prepared by the Monetary and Capital Markets and Western Hemisphere Departments

Approved by José Viñals and Nicolás Eyzaguirre

August 9, 2011

This report summarizes the findings of the Financial Sector Assessment Program (FSAP) for Chile. The assessment was undertaken in March-April 2011. The findings were further discussed with the authorities during the Article IV consultation mission in July 2011. The team comprised Marina Moretti (head, IMF); Augusto de la Torre (head, World Bank); Mariano Cortés (deputy head, World Bank); Jorge Chan-Lau, Javier Hamann, Elena Loukoianova, and Ryan Scuzzarella (all IMF); Tatiana Didier, Erik Feyen, Maria-Laura Patiño, and Craig Thorburn (all World Bank); Socorro Heysen, Peter Holtzer, Jonathan Katz, and Donald McIsaac (all external experts). The AML/CFT assessment was carried out by GAFISUD.

The key macro-relevant findings of the Financial System Stability Assessment (FSSA) are as follows:

- Chile's financial sector is one of the deepest in the region and is highly integrated in the global financial system. Banks are well capitalized, liquid, and highly profitable. Stress tests did not reveal near-term stability concerns, suggesting the banking system is likely to be resilient to adverse shocks. Earlier concerns with the solvency of the sizeable insurance industry have largely been addressed.

- Preventing a build-up of potential vulnerabilities should be the main focus of prudential policies, especially as capital flows may intensify, raising the risk of credit and asset price bubbles. Efforts to address information gaps to help firms assess credit risk and support the authorities in monitoring system-wide risks should therefore continue.

- Chile's financial regulatory and supervisory system is robust. Areas for further strengthening are independence and legal protection of regulatory authorities, the oversight of financial conglomerates, the AML/CFT framework, and the framework for the resolution of failed financial institutions. The authorities are rightly focused on improving the regulatory architecture while taking onboard a macroprudential function, and have recently established a Financial Stability Committee.

The FSAP also recommended steps to further improve access to finance for small and medium-sized firms.

FSAP assessments are designed to assess the stability of the financial system as a whole and not that of individual institutions. They have been developed to help countries identify and remedy weaknesses in their financial sector structure, thereby enhancing their resilience to macroeconomic shocks and cross-border contagion. FSAP assessments do not cover risks that are specific to individual institutions such as asset quality, operational or legal risks, or fraud. 
Glossary

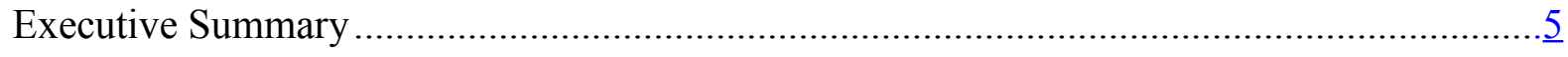

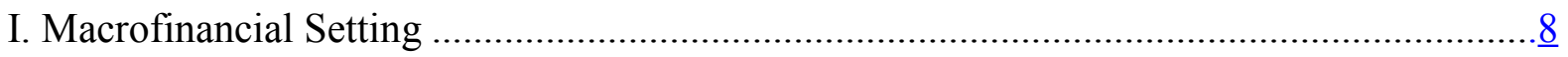

A. Macroeconomic and Financial Environment …………………………………...

B. Overview of the Financial System ……………………………….....................10

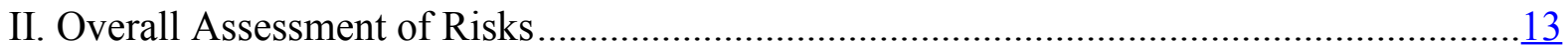

A. Soundness and Performance of Credit Institutions ……………………………...13

B. Institutional Investors .................................................................................

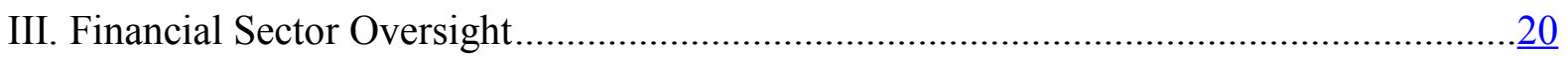

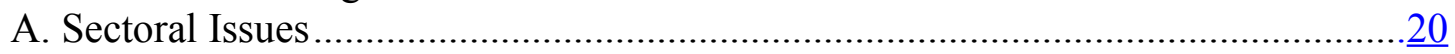

B. System-Wide Oversight ................................................................................

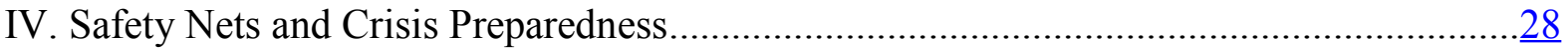

A. Observance of the IAIS Insurance Core Principles ………………………….......30

B. Implementation of the IOSCO Objectives and Principles of Securities Regulation $\underline{35}$

Tables

1. FSAP Update: Main Recommendations ....................................................................

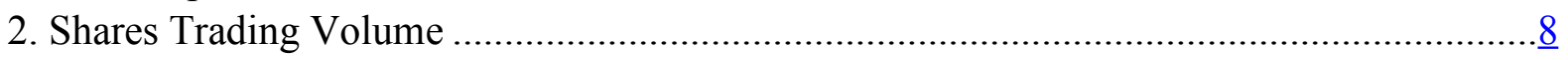

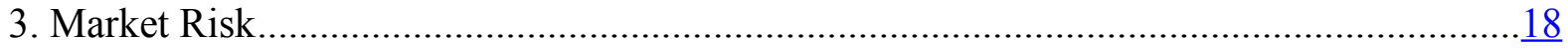

4. Summary Observance of the IAIS Core Principles ………………………………........

Figures

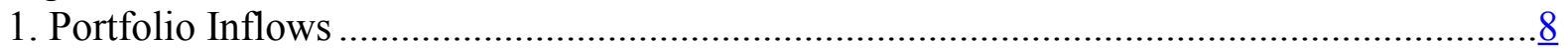

2. Stock Market Indices, Dedicated Fund Assets, ........................................................... 9

4. Financial System Assets, 2004-2010 ………………................................................

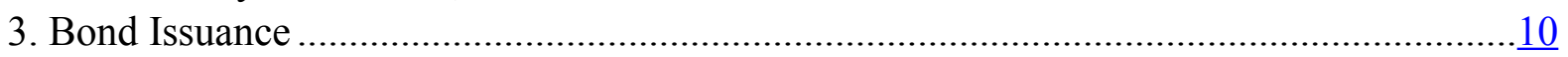

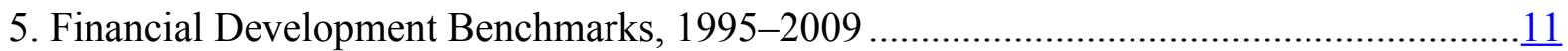

6. Major Gross Cross-Sectoral Financial Exposures, 2009 …………................................12

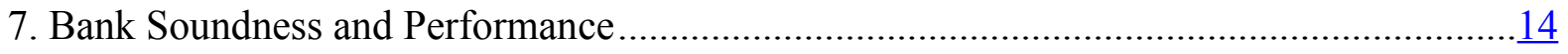

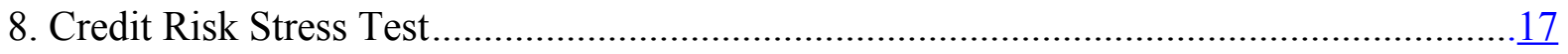

Boxes

1. Preparedness Toward Basel III Capital and Liquidity Requirements ...................................15

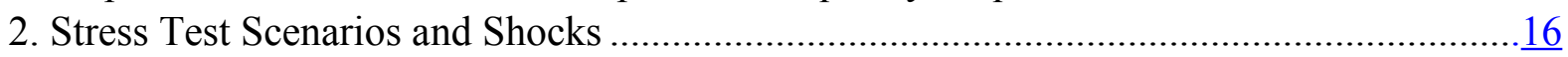

3. Consolidated Supervision: Further Efforts under the Current Legal Framework.................25

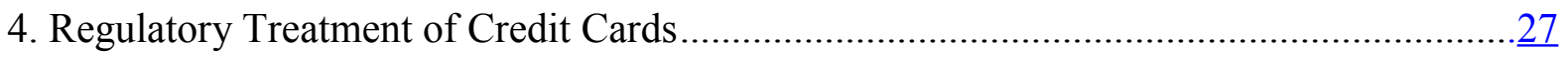


Appendixes

1. Main Recommendations of the 2004 FSAP

2. Risk Assessment Matrix

Annex Tables

5. Summary Implementation of the IOSCO Principles

6. Recommended Action Plan to Improve IOSCO Implementation.....................................44

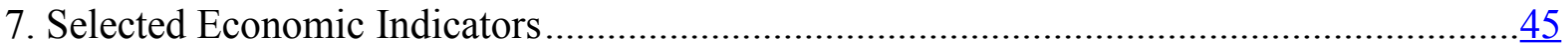

8. Financial System Structure ………………………….........................................

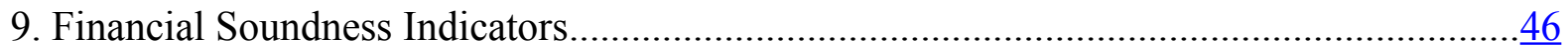

Annexes

1. Observance of Financial Sector Standards and Codes 


\section{GLOSSARY}

$\begin{array}{ll}\text { AAFM } & \text { Asociación de Administradoras de Fondos Mutuos de Chile } \\ \text { AFP } & \text { Pension fund administrator } \\ \text { AML/CFT } & \text { Anti-money laundering/combating the financing of terrorism } \\ \text { BCCh } & \text { Central Bank of Chile } \\ \text { CCLV } & \text { Central counterparty } \\ \text { DCV } & \text { Central securities depository } \\ \text { EPFR } & \text { Emerging Portfolio Fund Research, Inc. } \\ \text { FATF } & \text { Financial Action Task Force } \\ \text { FC } & \text { Financial conglomerate } \\ \text { FDI } & \text { Foreign direct investment } \\ \text { FSAP } & \text { Financial Sector Assessment Program } \\ \text { FSSA } & \text { Financial System Stability Assessment } \\ \text { GAFISUD } & \text { Financial Action Task Force of South America } \\ \text { GDP } & \text { Gross domestic product } \\ \text { IAIS } & \text { International Association of Insurance Supervisors } \\ \text { IFRS } & \text { International financial reporting standards } \\ \text { IFS } & \text { International financial statistics } \\ \text { IMF } & \text { International Monetary Fund } \\ \text { IOSCO } & \text { International Organization of Securities Commissions } \\ \text { LCR } & \text { Liquidity coverage ratio } \\ \text { MoU } & \text { Memorandum of understanding } \\ \text { NPL } & \text { Nonperforming loan } \\ \text { NSFR } & \text { Net stable funding ratio } \\ \text { ODC } & \text { Banks and cooperatives (other depository corporations) } \\ \text { OECD } & \text { Organisation for Economic Co-operation and Development } \\ \text { OTC } & \text { Over-the-counter } \\ \text { P\&A } & \text { Purchase and assumption } \\ \text { ROA } & \text { Return on average assets } \\ \text { ROE } & \text { Return on average equity } \\ \text { ROSC } & \text { Report on the Observance of Standards and Codes } \\ \text { SBIF } & \text { Superintendence of Banks and Financial Institutions } \\ \text { SP } & \text { Superintendence of Pensions } \\ \text { SVS } & \text { Superintendence of Securities and Insurance } \\ \text { UF } & \text { Unidad de fomento (a unit of account) } \\ \text { VAR } & \text { Vector auto-regression } \\ \text { VIX } & \text { Volatility index } \\ & \end{array}$




\section{EXECUTIVE SUMMARY}

\section{The Chilean economy has bounced back strongly following the global financial crisis} and a major earthquake. The financial system weathered the crisis well - the result of overall strong balance sheets and profitability, a robust regulatory framework, and timely action by the authorities to counter pressures on liquidity and the supply of credit during the crisis. Looking ahead, strong growth and a favorable interest rate differential could continue to attract capital inflows, raising the risk of credit and asset price bubbles. Remaining vigilant in this area will require continued efforts to address information gaps, notably through the construction of standardized indices for real estate prices and the proposed consolidated credit registry.

\section{The financial system is large, well diversified, and highly integrated into the global} financial system. It is the deepest in the region and compares well with its peers. A key feature is its high degree of conglomeration. Interlinkages within the financial system involve mainly asset managers and banks - the former investing in the latter the equivalent of about a quarter of GDP. Interlinkages among banks are relatively low. Gross financial savings of Chilean households are high (about 140 percent of GDP) and nearly half of them are placed in pension funds. Gross liabilities of corporates are over one time GDP; only a small fraction is owed to banks and a larger fraction to the rest of the world.

\section{The financial system appears resilient overall but challenges remain:}

- $\quad$ Banks are well capitalized (in terms of both quantity and quality of capital) and profitable, and significant core deposits substantially limits funding risks. Although stress tests confirm that they can withstand severe macroeconomic shocks in terms of solvency and liquidity, pockets of vulnerability remain among some small banks that rely substantially on wholesale funding.

- $\quad$ The solvency of insurance companies has improved since the 2004 FSAP — a result of tighter retirement qualifications and crisis-induced losses in pension portfolio, both of which have reduced early retirement. Price formation in the annuity industry has improved significantly following the introduction of a transparent quotation system, advisor qualification standards, and ceilings on brokers' commissions. However, competitive pressures on profitability could again pose challenges going forward.

- $\quad$ Pension funds ' risks are now better diversified, including internationally, and the introduction of default portfolios that follow life cycle criteria has better aligned investments with the long-term interests of pension fund contributors. Important steps have been taken to improve efficiency and competition in the system. Looking ahead, lower returns may require increases in contribution rates and the retirement age. The high profits of pension fund administrators may come under scrutiny in that context. 
Sectoral oversight of the financial system is robust but there is room for improvement in some areas. Ongoing reforms to strengthen the supervisory framework should provide an opportunity to enhance the independence and legal protection of regulators. In banking, the priority is to complete the incorporation of Basel II and III capital standards. To improve integrity in insurance markets, the relevance and quality of the actuarial profession needs to be boosted. The authority of the securities regulator should be augmented, especially with respect to enforcement powers and the ability to regulate all investment advisors. Finally, there is a need to further enhance the framework for anti-money laundering and combating the financing of terrorism (AML/CFT).

With a financial structure dominated by conglomerates, Chile has a critical need to strengthen consolidated supervision. The lack of a comprehensive framework for the consolidated oversight of financial conglomerates is an increasingly serious gap - although firewalls help limit the build-up of intra-group exposures. The authorities have taken a range of actions to strengthen conglomerates oversight and related-party exposures are strictly limited. While there is some room for further improvement within the current legal framework, major legal reforms are needed to provide regulators with the powers to supervise conglomerate risks effectively.

\section{At present, the prudential and business conduct regulatory playing field is not sufficiently level. Asymmetries exist in licensing, suitability standards, disclosure, and compliance requirements across institutions that offer similar asset management services and investment advice. A more harmonized approach to custody, clearing, and settlement infrastructure could also improve efficiency and reduce systemic risk. The extent to which the retailers' credit card operations should be brought more fully into the perimeter of regulation requires careful consideration. More generally, the potential emergence of high leverage outside the regulatory perimeter needs to be closely monitored.}

The authorities are rightly focused on improving the regulatory architecture while taking onboard a macroprudential function. A welcome step is the recent establishment of a Financial Stability Committee to oversee system-wide risks but caution will be needed to ensure that the Committee can discharge its functions effectively. In particular, the central bank is an observer on the Committee and in that role it should be able to adequately influence the Committee's deliberations, while preserving its autonomy. Moreover, in normal times any institution-specific issues should be delegated to a sub-committee of supervisors to avoid weakening regulatory independence.

The framework for crisis management and resolution would benefit from a number of enhancements. In particular, there is room to improve the bank resolution framework. Critical areas for reform include establishing powers to dilute existing shareholders before liquidation, enhancing legal protection for regulators and interventors, and expanding the range of resolution tools. The authorities see the need to review the bank resolution 
framework and are conducting a crisis simulation exercise to determine areas of possible improvement. In addition, although less urgent, the authorities will need to consider establishing a framework for dealing with systemic cases, and for the potential failure of a conglomerate. As the resolution framework is strengthened, consideration should be given to establishing a premium-based limited deposit insurance scheme.

Table 1.Chile: FSAP Update: Main Recommendations ${ }^{1}$

\begin{tabular}{|c|c|c|}
\hline Recommendation & $\begin{array}{c}\text { Priority } \\
\text { (H/M) }\end{array}$ & $\begin{array}{c}\text { Time } \\
\text { Frame } \\
\text { (S/M) }\end{array}$ \\
\hline \multicolumn{3}{|l|}{ Addressing system- wide risks } \\
\hline $\begin{array}{l}\text { Reduce information gaps, including through a consolidated credit registry and standardized } \\
\text { residential and commercial property price indices }(\S 4)\end{array}$ & M & M \\
\hline Develop a strategy to ensure adequate replacement rate for retirees $(\S 17)$ & $\mathrm{H}$ & M \\
\hline \multicolumn{3}{|l|}{ Financial Sector Oversight } \\
\hline Strengthen the independence and legal protection of regulatory agencies $(\S 22)$ & $\mathrm{H}$ & M \\
\hline Complete the incorporation of Basel bank capital standards $(\S 21)$ & $\mathrm{H}$ & M \\
\hline Strengthen enforcement powers of securities regulators $(\S 27)$ & $\mathrm{H}$ & $\mathrm{S}$ \\
\hline $\begin{array}{l}\text { Establish legal framework to enable the consolidated oversight of financial conglomerates } \\
(\S 31-34)\end{array}$ & $\mathrm{H}$ & M \\
\hline $\begin{array}{l}\text { Enhance uniformity in business conduct regulation for asset management services and } \\
\text { investment advice }(\S 36)\end{array}$ & $\mathrm{H}$ & M \\
\hline $\begin{array}{l}\text { Introduce comparable transparency standards for fixed income securities traded outside } \\
\text { exchanges }(\S 37)\end{array}$ & $\mathrm{H}$ & M \\
\hline Adopt a comprehensive approach to custodial, clearing, and settlement infrastructure ( $\S 37)$ & M & M \\
\hline Further enhance the AML/CFT framework $(\S 28-30)$ & M & M \\
\hline \multicolumn{3}{|l|}{ Resolution Framework } \\
\hline Strengthen legal framework for bank resolution $(\S 42-43)$ & $\mathrm{H}$ & M \\
\hline Consider introduction of a premium-based limited deposit insurance system ( $(45-46)$ & M & M \\
\hline $\begin{array}{l}\text { Examine options to establish a framework for dealing with a systemic crisis and with the } \\
\text { potential failure of a financial conglomerate }(\S 42)\end{array}$ & $\mathrm{M}$ & M \\
\hline
\end{tabular}

\footnotetext{
${ }^{1}$ H/M: High or medium priority. S/M: suggested timetable for implementation (short or medium term).
} 


\section{Macrofinancial Setting}

\section{A. Macroeconomic and Financial Environment}

1. After experiencing two major shocks - the 2008 global financial crisis and the 2010 earthquake - the Chilean economy has bounced back strongly. In 2009, real GDP contracted by 1.5 percent but the economy recovered in the next year. Real GDP grew 5.5 percent in 2010 and is projected to grow by 6.5 percent in 2011 (Table 7). Improved consumer confidence, normalized credit and liquidity conditions, and the momentum from earthquake reconstruction have supported growth in 2011. On the back of the strong outlook, monetary policy has moved to a tightening stance since mid-2010.

\section{Strong growth and a favorable interest rate differential may intensify capital} inflows, raising the risk of asset price and credit bubbles. In 2010, domestic investment benefitted from strong FDI inflows and all time high portfolio inflows (Figure 1). The inflows were largely offset by portfolio outflows as domestic pension funds increased their foreign asset allocation. As a result, asset price and credit growth was contained and corporate debt-to-GDP and household debt-to-disposable income ratios remain broadly stable. ${ }^{2}$ However, as yields on domestic assets rise relative to foreign yields and pension fund outflows moderate, capital inflow pressures may intensify. The impact on domestic equity prices of inflows from Latin Americadedicated funds could be particularly pronounced, because the free float in Chile is a small fraction of market capitalization and is concentrated among few stocks (Table 2 and Figure 2).

Figure 1. Chile: Portfolio Inflows (in percent GDP)

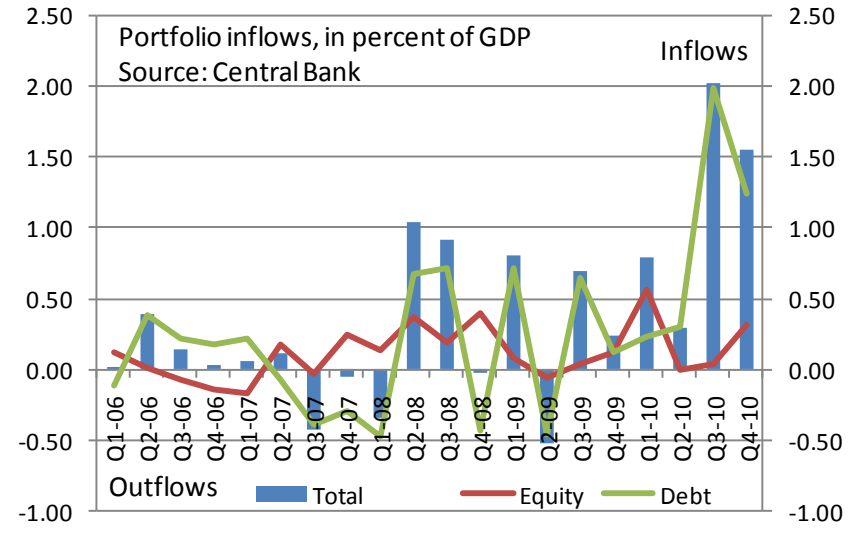

Table 2. Chile: Shares Trading Volume (in percent of total market capitalization)

\begin{tabular}{lrrrrrrr}
\multicolumn{7}{l}{ Shares trading volume, in percent of total market capitalization } \\
\hline & 2003 & 2004 & 2005 & 2006 & 2007 & 2008 & 2009 \\
\hline Brazil & 29.3 & 31.5 & 34.8 & 38.9 & 43.7 & 122.3 & 46.8 \\
Chile & 7.6 & 10.4 & 13.9 & 17.0 & 22.5 & 27.5 & 16.5 \\
Colombia & 5.7 & 8.2 & 18.7 & 26.4 & 16.5 & 23.1 & 13.3 \\
Mexico & 21.1 & 26.4 & 23.7 & 27.8 & 36.2 & 47.2 & 23.9 \\
Peru & 8.1 & 8.7 & 11.0 & 13.7 & 16.2 & 16.7 & 6.3 \\
\hline
\end{tabular}

Source: World Federation of Exchanges

\footnotetext{
${ }^{2}$ Credit has grown in line with rising income in 2010 , and real estate prices appear broadly stable based on available data. The central bank noted in late 2010 that the stock market could be overvalued but prices have declined recently and price-earnings ratios suggests equities are fairly priced compared to historical values.
} 


\section{Figure 2. Chile: Stock Market Indices, Dedicated Fund Assets, and Portfolio Equity Inflows}

Brazil 1/

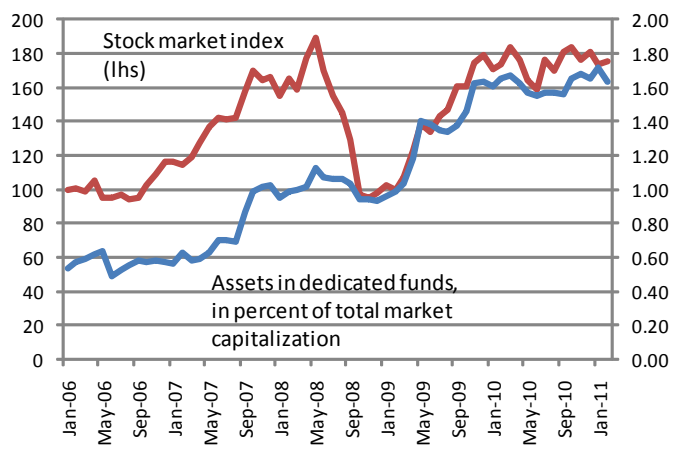

Colombia 1/

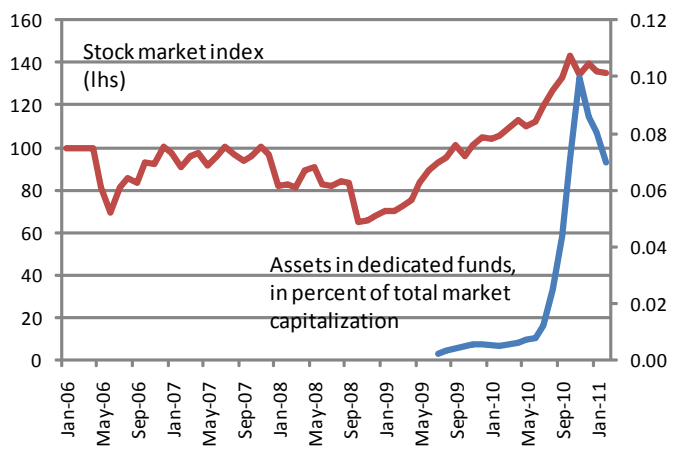

Peru 1/

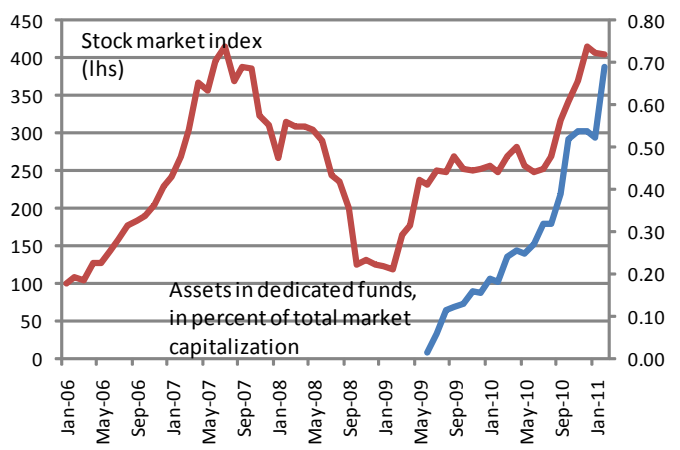

Chile 1/

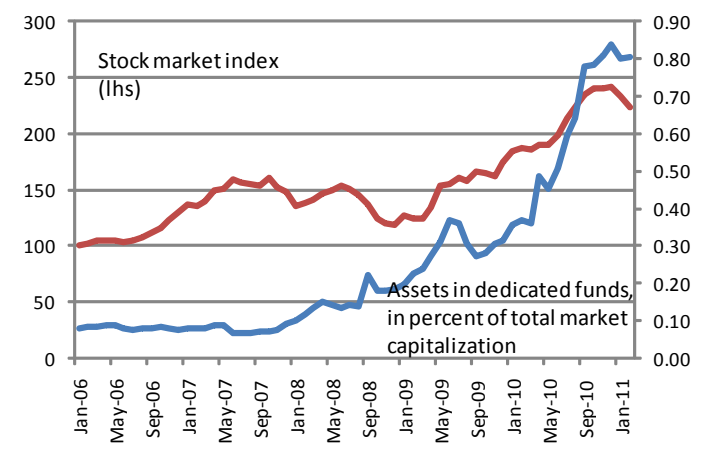

Mexico 1/

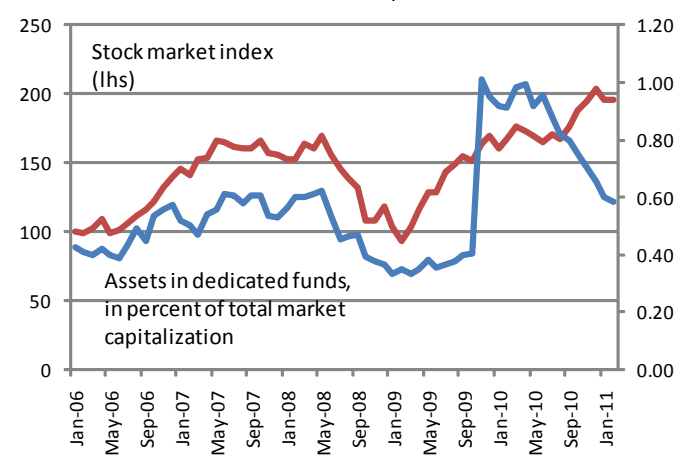

Equity inflows, in percent of share trading volume 2/

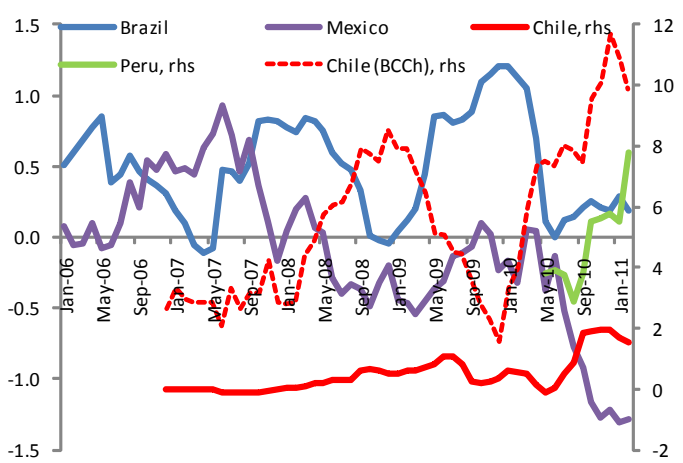

1/ Stock market indices: Brazil (Bovespa), Chile (IGPA), Colombia (IGBC), Mexico (IPC), Peru (IGBVL); assets in dedicated funds, EPFR.

2/ Equity inflows correspond to mutual funds and exchange traded funds inflows reported by EPFR with the exception of Chile (BCCh). In the latter case, equity inflows correspond to portfolio investment inflows of FICEs and other funds reported by the Central Bank of Chile. The flows are calculated as cumulative flows over a

12 month window. Equity inflows for countries other than Chile may be under-estimated since EPFR only captures mutual funds and ETFs flows. 
3. External borrowing by banks and corporates is likely to continue and warrant continued monitoring. Corporate bond issuance in 2010, at US\$ 12.8 billion, was flat relative to 2009 but the share of external issuance rose to 80 percent from 50 percent (Figure 3). Given easy access to international markets and the availability of currency derivatives, large corporates (reportedly mostly exporters) may well increase their indebtedness abroad in 2011 as local funding costs rise. Repatriation of assets by domestic pension funds, on the other hand, could put downward pressure on rates, facilitating either bank borrowing or domestic issuance. Currency mismatches by corporates remain limited (7 percent of assets) though reliance on external debt could expose them to changes in external funding conditions.

Figure 3. Chile: Bond Issuance (in US\$ million)

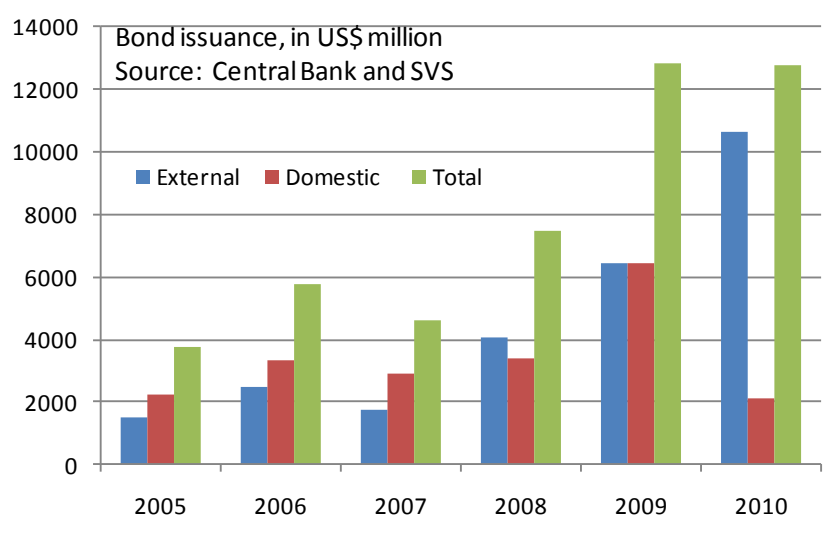

4. Given potential pressures, efforts to address information gaps to support systemwide monitoring and the prudent assessment of credit risks should continue. In particular, the construction and publication of standardized house and commercial property price indices to help detect price misalignments should be a priority. The proposed consolidated credit registry including comprehensive information from both banks and other credit providers (including department stores) will help improve the assessment and pricing of credit risk for firms and households.

\section{B. Overview of the Financial System}

5. The Chilean financial sector is large and highly integrated in the global financial system. As of end-2010, gross financial system assets accounted for over twice GDP, making it one of the deepest in the region (Figures $4-5$ ). At the core of the system are banks (over half of which are foreign-owned) and the mandatory, privately administered pension system. The insurance sector (mainly annuities linked to the pension system) and mutual funds are also key players (Table 8). Firms and households are highly integrated, including to global financial markets (Figure 6).

Figure 4. Chile: Financial System Assets, 2004-2010 (Percent of GDP)

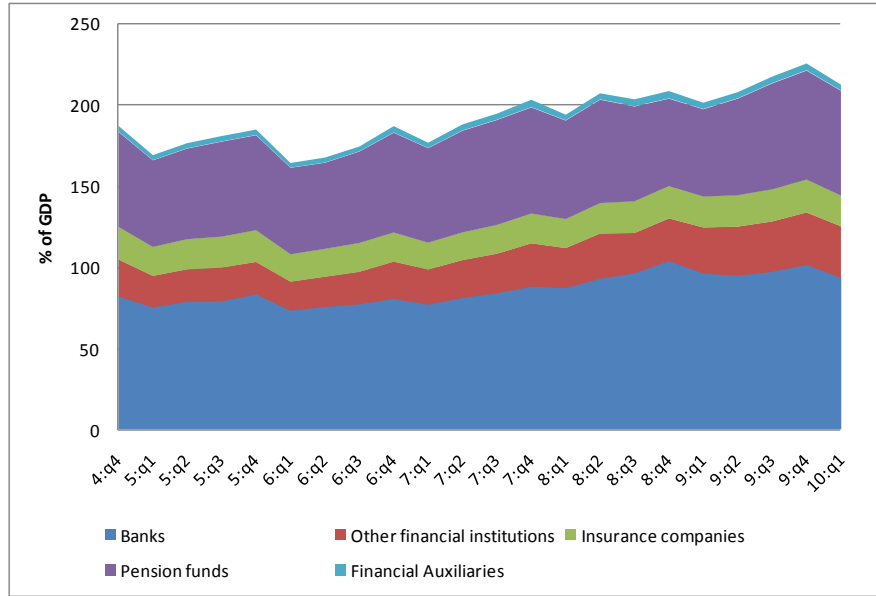


Figure 5. Chile: Financial Development Benchmarks, 1995-2009

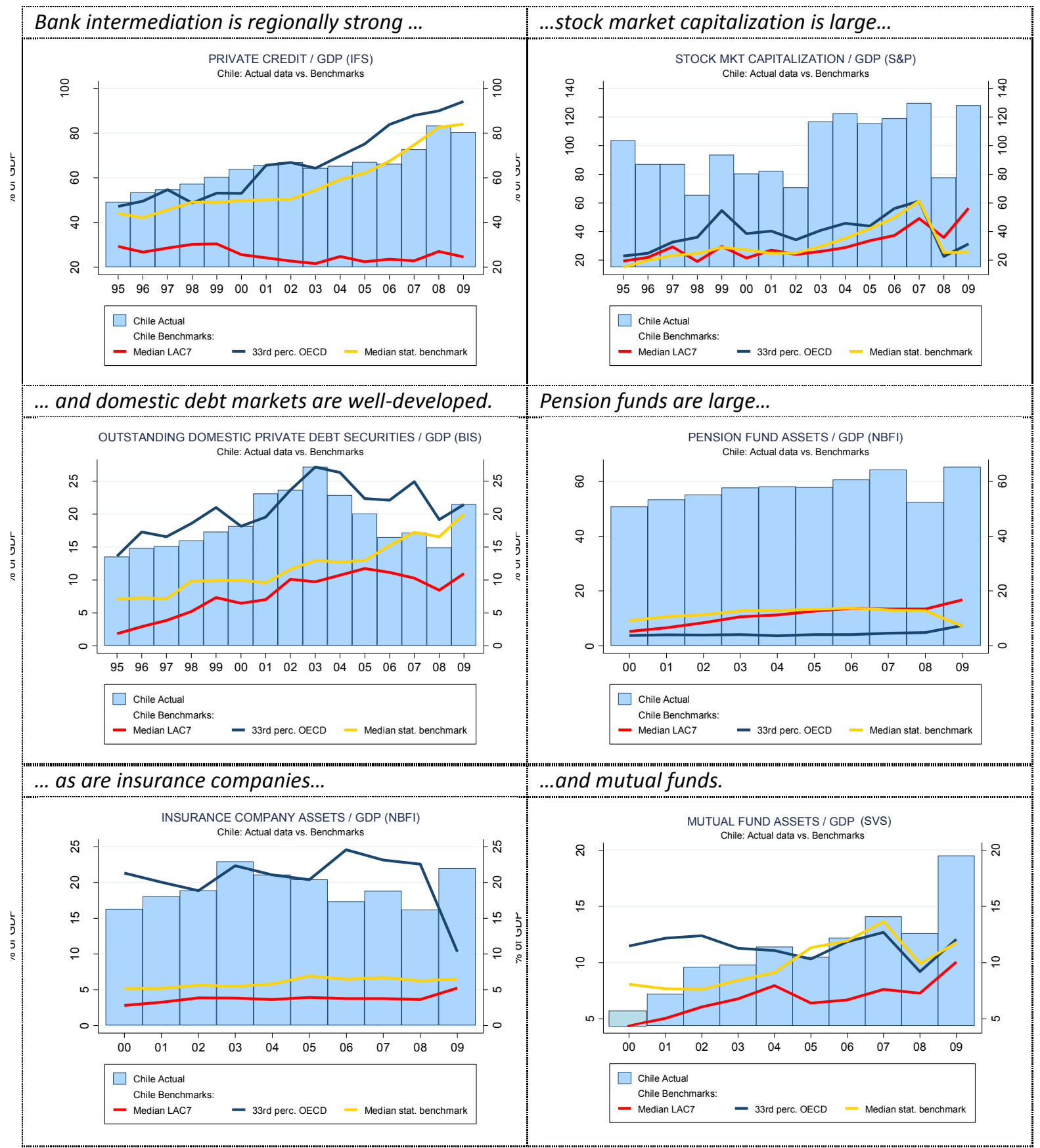

Sources: BCCh, Superintendence of Insurance and Securities (SVS), World Bank, Bank for International Settlements (BIS), IMF, and World Bank staff estimates.

Notes: $-\mathrm{AC} 7$ " consists of Argentina, Brazil, Chile, Colombia, Mexico, Peru, and Uruguay. Median stat. benchmark" is the expected median value for Chile based on a global, multi-year quantile regression model that accounts for the country's GDP per capita, population size and density, old and young age dependency ratios, and its status as a fuel exporter, offshore financial center, and transition country. The 33 percent OECD" represents the $33^{\text {rd }}$ percentile of the OECD countries. 
Figure 6. Chile: Major Gross Cross-Sectoral Financial Exposures, 2009 (In percent of GDP)

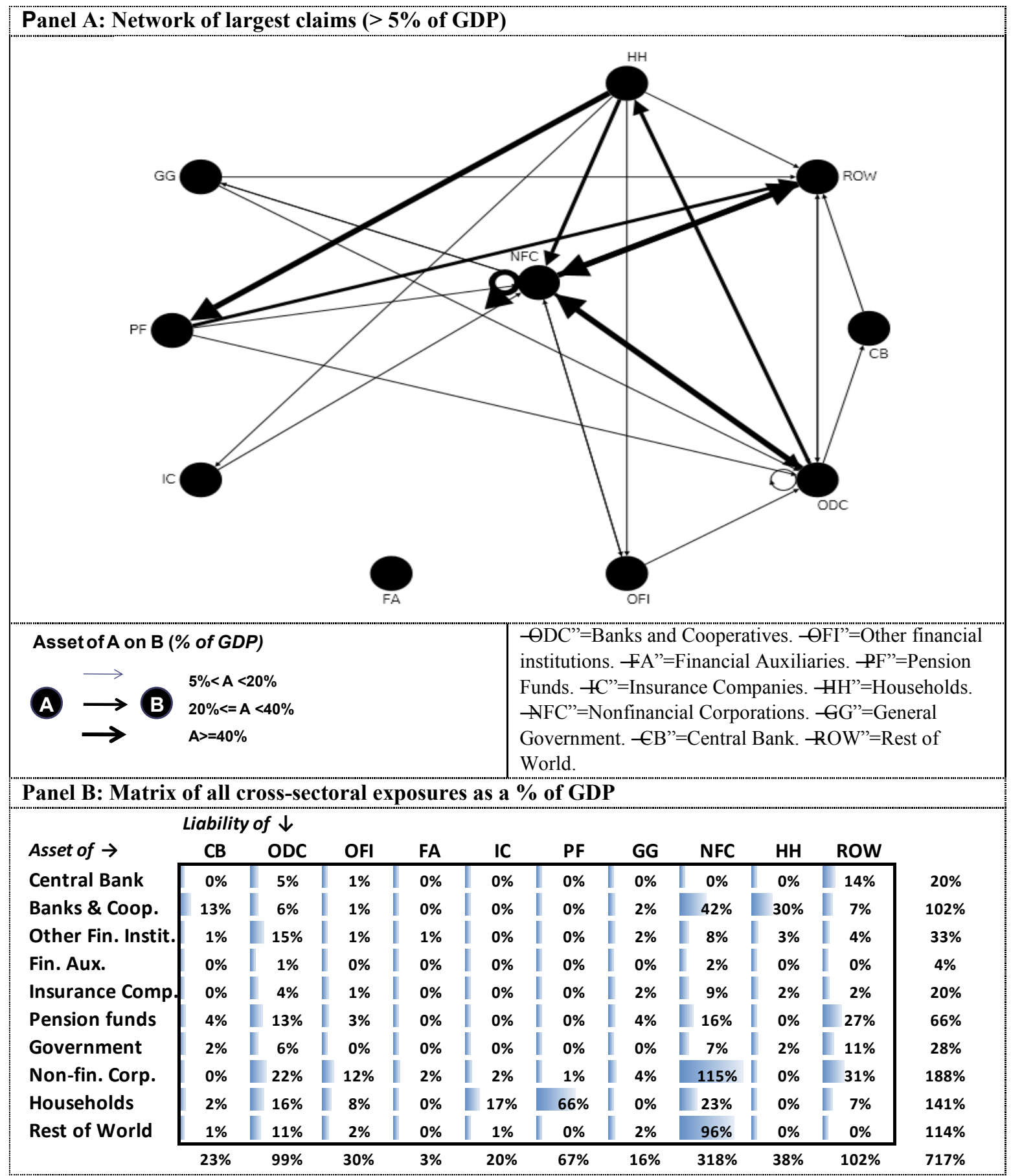

Sources: BCCh (Financial Accounts) and World Bank staff estimates.

Notes: Exposures exclude net derivative positions. Preliminary BCCh estimates of long-term securities positions (item AF.32) are included. World Bank staff estimates of shares and other equity — excluding mutual funds - (item AF.51) and other accounts (item AF.7) are based on maximum entropy methods. 
By international comparison, the gross financial savings of Chilean households are high and invested in a diversified manner (by intermediary and location) across pension funds, insurance policies, bank deposits, and direct claims on local firms. Nonfinancial firms are by far the largest ultimate borrowers and as noted earlier, receive sizeable funding from abroad.

6. The Chilean financial system has a high degree of conglomeration (including mixed conglomerates). Most financial institutions in Chile are owned by conglomerates operating in two or more financial sectors. In terms of assets, the 10 largest conglomerates account for 77 percent of assets in the banking industry, 65 percent in insurance, 85 percent in investment and mutual funds, 91 percent in brokers, and 42 percent in pension funds.

\section{Overall AsSessment OF Risks}

\section{A. Soundness and Performance of Credit Institutions}

7. Chilean banks are well capitalized, highly profitable, and liquid (Figure 7 and Table 9). Bank capital is high and of high quality (common equity accounts for 44 percent of regulatory capital); and leverage is constrained by regulation. Capital and leverage are already largely within the new Basel III standards (Box 1). The cyclical deterioration in loan quality experienced during the crisis has started to reverse, and provisions are at comfortable levels. ${ }^{3}$ Returns on assets and equity are comparable to other countries in the region but relatively high by international standards. While the recovery in lending in recent months has supported earnings, high margins (especially in retail lending) and relatively low overheads also contributed to high profitability. In addition, banks ${ }^{6}$ long inflation-indexed positions can be an important source of earnings in periods of growing inflation. ${ }^{4}$

8. Banks are liquid and rely mainly on core deposits for funding. Liquid assets were 20 percent of total assets at end-2010, and retail deposits accounted for one third of liabilities. Banks have experienced a decline in wholesale deposits from pension funds and lower mutual funds deposits are expected going forward as money market funds move to mark-to-market valuations and become less attractive to investors (but would make bank deposits relatively more attractive). Some smaller banks that rely more on wholesale funding could be vulnerable to these developments, though to date the reduction in wholesale funding has been offset by higher retail deposits (partly due to higher policy rates) and bond issuance domestically and offshore (the latter equivalent to 2 percent of liabilities as of April 2011). Banks ${ }^{6}$ access to international markets was at favorable terms during 2010 and has resulted in a longer-term borrowing structure; due to hedging, foreign exchange exposures appear limited.

\footnotetext{
${ }^{3}$ Nonperforming loans are more pronounced in the mortgage segment (4.9 percent of total mortgage loans), but this is almost entirely explained by the state-owned bank, which specializes on low-income borrowers.

${ }^{4}$ Many loans, deposits, and securities in Chile are expressed in UFs (Unidad de Fomento), an indexed unit of account. The exchange rate between UFs and pesos fluctuates with inflation.
} 
Figure 7. Chile: Bank Soundness and Performance

The system is well capitalized...

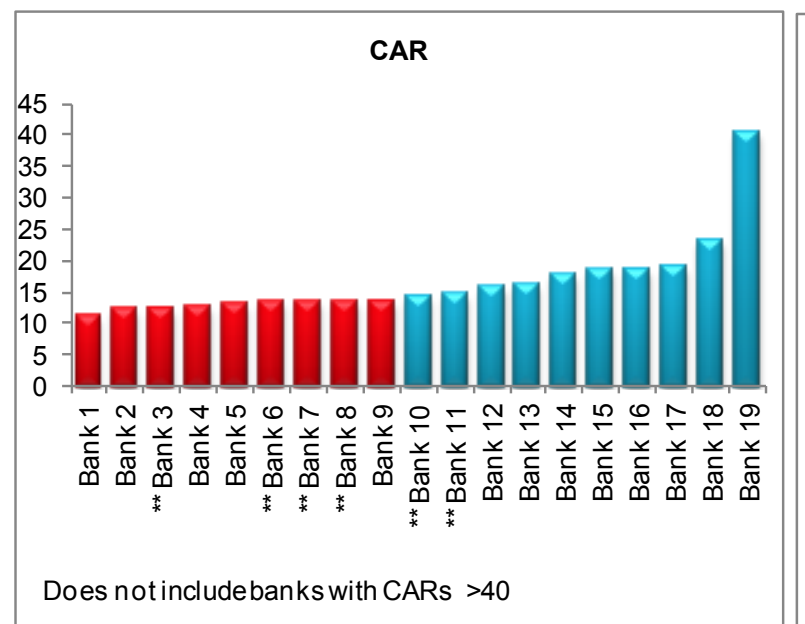

Bank liquidity levels have recovered ...

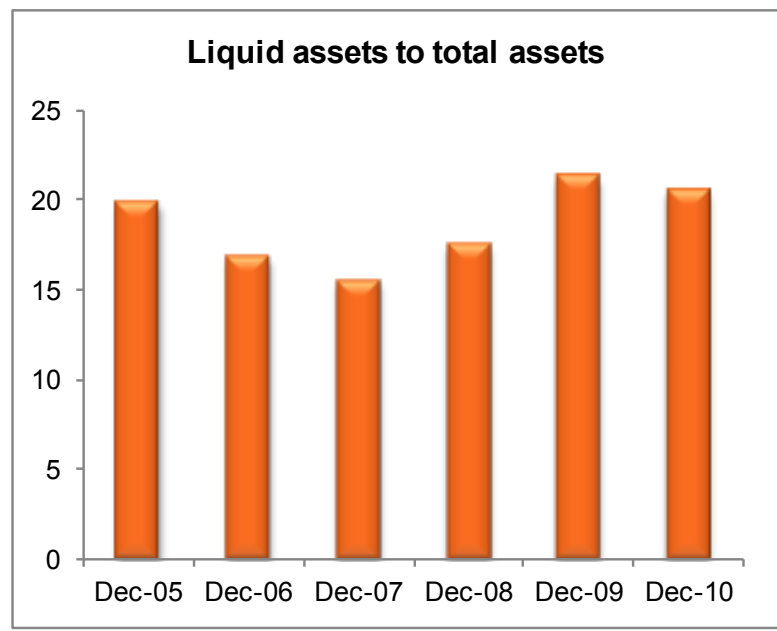

Average system profits are high...

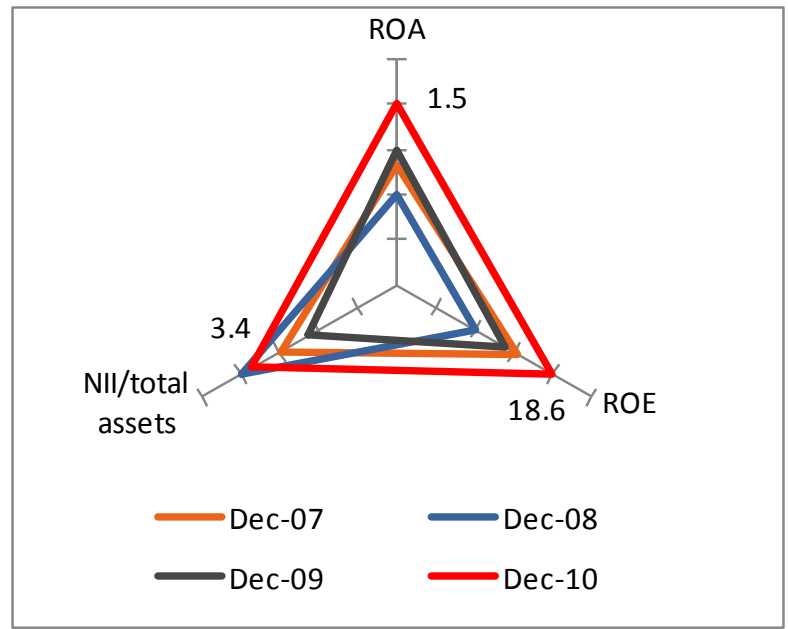

and NPLs are overall low and improving.

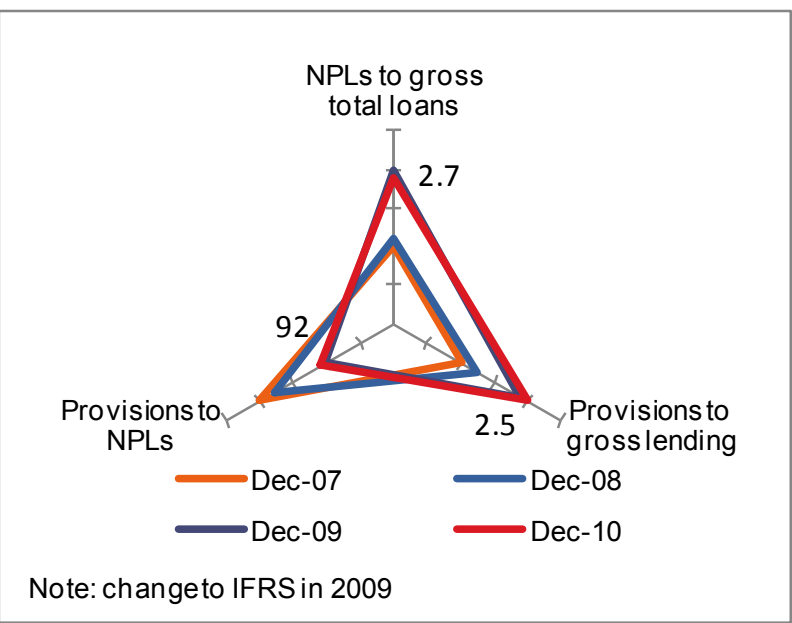

despite lower reliance on pension funds.

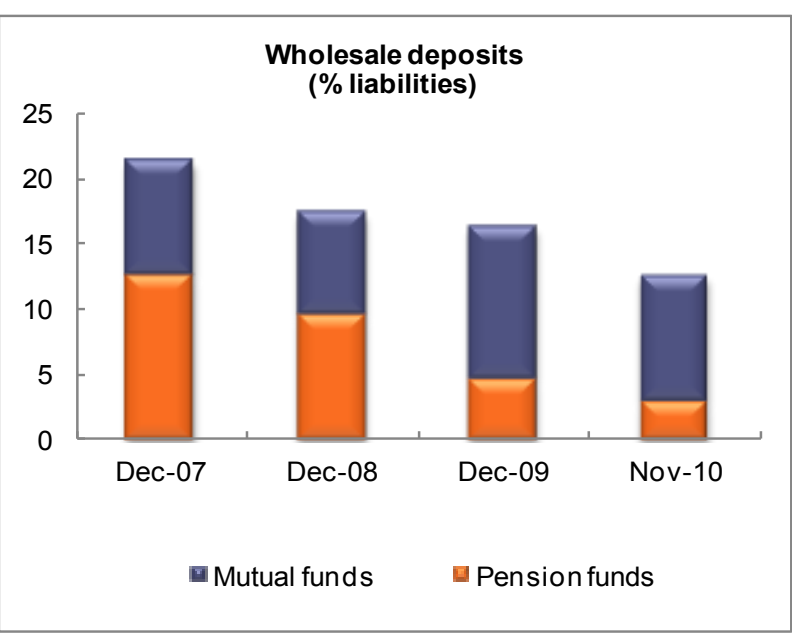

but comparable to others in the region.

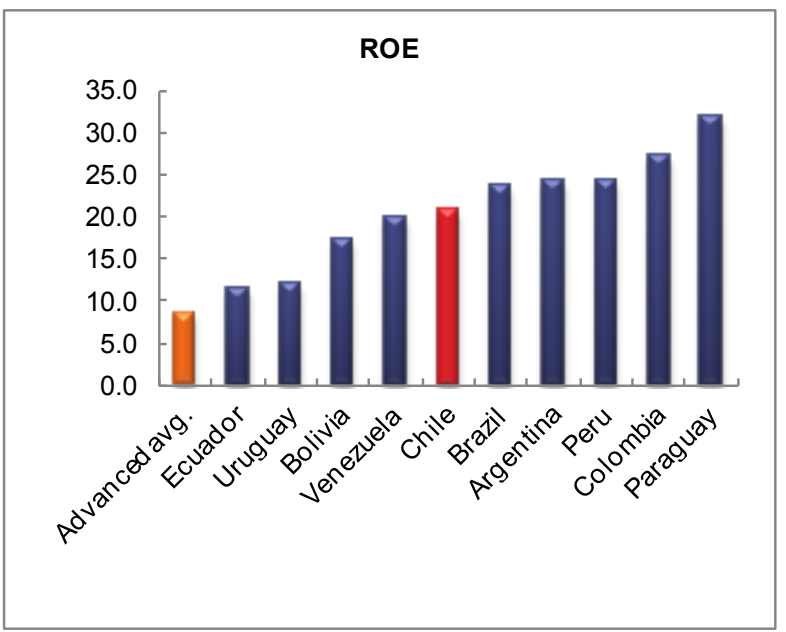




\section{Box 1. Preparedness Toward Basel III Capital and Liquidity Requirements}

The new capital and liquidity requirements within the Basel III framework are due to be implemented over 2015-2019. Estimations carried out by the BCCh and the banking superintendence (SBIF), and liquidity and solvency stress tests demonstrate that these requirements would not be particularly difficult to meet for domestically incorporated banks.

As regulatory capital mainly consists of high quality capital (almost 65 percent of Tier 1 capital is common equity), the new capital standards would not be overly restrictive for Chilean banks. Core capital (currently equivalent to Tier 1 capital) and total capital are above the minimum level agreed under Basel III. Similarly, the leverage ratio proposed under Basel III was introduced by the general banking law some time ago, and over the last decade system's leverage (as measured by Tier 1 capital to assets) has always exceeded 6 percent.
Chile: Banking System's Capital Standards (percent of risk-weighted assets)

\begin{tabular}{lrr}
\hline & $\begin{array}{c}\text { Basel III } \\
2019\end{array}$ & $\begin{array}{c}\text { Chile } \\
\text { Dec. 2010 }\end{array}$ \\
\hline Tier 1 & 6.0 & 10.1 \\
Conservation buffer & 2.5 & $\ldots$ \\
Total capital & 8.0 & 14.1 \\
Total capitl + buffer & 10.5 & $\ldots$ \\
Countercyclical buffer & 0 to 2.5 & $\ldots$ \\
Tier 1 (percent total assets) & 3.0 & 7.1 \\
\hline
\end{tabular}

For the liquidity standards, the Chilean regulatory framework establishes 30 - and 90-day mismatch limits in domestic and foreign currencies. The liquidity stress tests for the liquidity coverage ratio (LCR) and net stable funding ratio (NSFR), conducted in the context of this FSAP Update, show that the banking system is well positioned to meet the LCR by 2015 and the NSFR by 2019. For the LCR, seven banks pass the LCR stress test, with the average LCR for the system currently standing at 0.66 , with the liquidity shortfall is estimated at only 10 percent of the total assets. In the case of the NSFR, 23 banks pass the stress test, with the remaining two small banks (around 5 percent of the system's total assets) being in the $75^{\text {th }}$ percentile. The available stable funding is estimated at 91 percent of the total assets, while the required stable funding is estimated at 71 percent of total assets, with the overall liquidity shortfall at only 0.5 percent of the total funding liquidity.

\section{9. $\quad$ Stress tests confirm that banks are well positioned to withstand severe shocks.} Several stress tests were undertaken jointly by the BCCh, SBIF, and the FSAP team, testing all 25 banks in the system for exposure to credit, market, and liquidity risk. The baseline scenario was consistent with the IMF's World Economic Outlook while the adverse scenario was predicated on further shocks to demand and output (Box 2).

\section{Credit risk stress tests indicate that the system is overall resilient to increases in} credit risk. The tests were computed using a nonlinear vector auto-regression (VAR) model, where banking system aggregates include loan loss provision, credit growth, and write-offs, while macroeconomic variables include output growth, short- and long-term interest rates, and unemployment rate. Under the risk scenario, the banking system remains profitable and well capitalized (Figure 8). ${ }^{5}$ Pockets of vulnerability in terms of ROE decline remain in a few small and systemically unimportant banks.

\footnotetext{
${ }^{5}$ ROEs would decline by about 10 percent under the risk scenario at the end of a two-year period. Despite a significant reduction in credit growth, capital adequacy remains well above 10 percent for all banks.
} 


\section{Box 2. Stress Test Scenarios and Shocks}

The Baseline Scenario for the credit risk tests was the scenario from the IMF's January 2011 World Economic Outlook update. GDP growth rises to 5.2 percent in 2011 (current authorities' estimates are 6.6. percent for 2011) from 5.1 percent in 2010, and then fluctuates around the 5.0 percent long-term trend; short-term interest rates and unemployment rise gradually to 5.43 and 8.0 percent, respectively, by 2015. Long-term interest rates are also assumed to rise gradually.

A Severe Risk Scenario for the credit risk tests was generated using the $\mathrm{BCCh}$ 's reduced form and stochastic general equilibrium economy models. The scenario is based on the January 2011 World Economic Outlook update risk scenario, made adverse in four respects: (i) an increase in country premium spread by 50 bps; (ii) an additional shock in VIX of $40 \mathrm{bps}$; (iii) a negative demand shock in the United States and emerging Asia of 1 and 0.2 percent, respectively, feeding through lower terms of trade; and (iv) a negative domestic demand shock in consumption and investment. These assumptions are consistent with an increase of risks in peripheral Europe, such that funding costs for emerging market countries would increase, thereby depressing real sector activity in Chile. ${ }^{1}$ Reflecting this combination of shocks, economic growth falters to 1.8 and 3.6 percent in 2011 and 2012 respectively, with a permanent shock resulting in a lower (4 percent) GDP growth in the long run. The 2011 GDP growth shock corresponds to a three standard deviation (over a 20-year period) decline in GDP growth. The risk horizon for the macro stress tests is 5 years.

Single factor shocks for market risk stress tests were also employed. The calibration of these shocks was based on Chilean historical data for the last 20 years as well as experience from other countries. The exchange rate risk was modeled as a 20 percent depreciation of the nominal exchange rate vis-à-vis the U.S. dollar over a 15-day period, reflecting for instance a sharp decline in copper prices - which much more severe than the highest historical nominal depreciation (of 6.75 percent in October 2009). The interest rate shock was modeled as a sharp increase in short-term and long-term interest rates by 250 and 100 bps respectively, with the shock dying out gradually over a three-year horizon.

The liquidity stress tests assumed funding or market liquidity stresses, modeled as shocks to individual banks ${ }^{6}$ deposit and wholesale funding base - including a sudden, substantial withdrawal of funding over five periods (approximately 10 percent on average each period). These were reverse stress tests-hypothetical tests against the withdrawals that would break" the system. This exercise also tested for preparedness for the new Basel III requirements - the LCR and the NSFR.

${ }^{1}$ Low direct exposure would limit the impact on Chilean banks. While subsidiaries of Spanish banks account for a quarter of banking system's assets, related-party transaction limits protect against sudden outflows of liquidity. Moreover, correlations between stock prices of local banks (including Spanish subsidiaries) and Spanish banks have come down and are quite low.

\section{Market risks appear manageable and are largely driven by interest rate risk} (Table 3). The calculations were conducted using a VAR that models each cash flow in the portfolio as well as the yield curve using factors. The VAR follows a discrete-time version of the model, in which the parameters are dynamic factors. ${ }^{6}$ Medium-size and treasury banks (which are particularly active in trading) appear most affected in a stressed scenario in which both short- and long-term interest rates increase. Large banks are least affected by market risks, partly reflecting the diversified nature of their activities.

\footnotetext{
${ }^{6}$ See Alfaro and Sagner (2010). - Stress Tests for Banking Sector: A Technical Note," Central Bank of Chile, Working Paper No. 610 (February).
} 
Figure 8. Chile: Credit Risk Stress Test

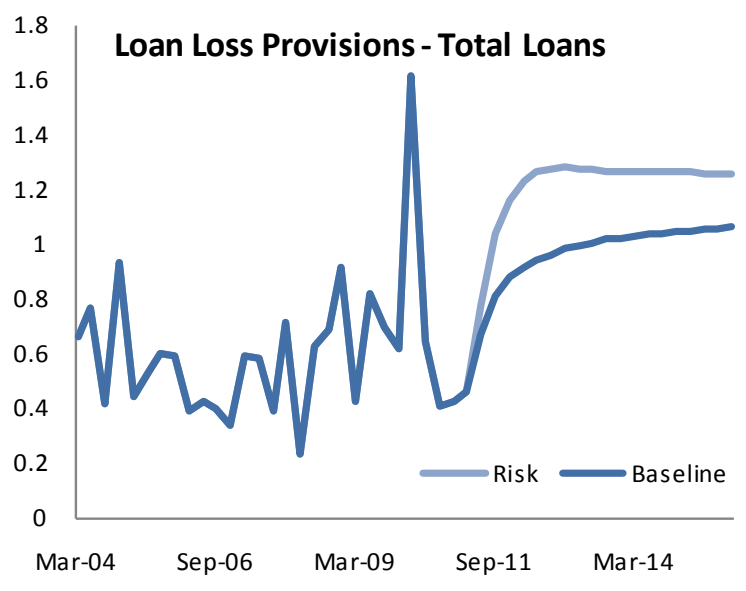
Credit Risk - Total Loans
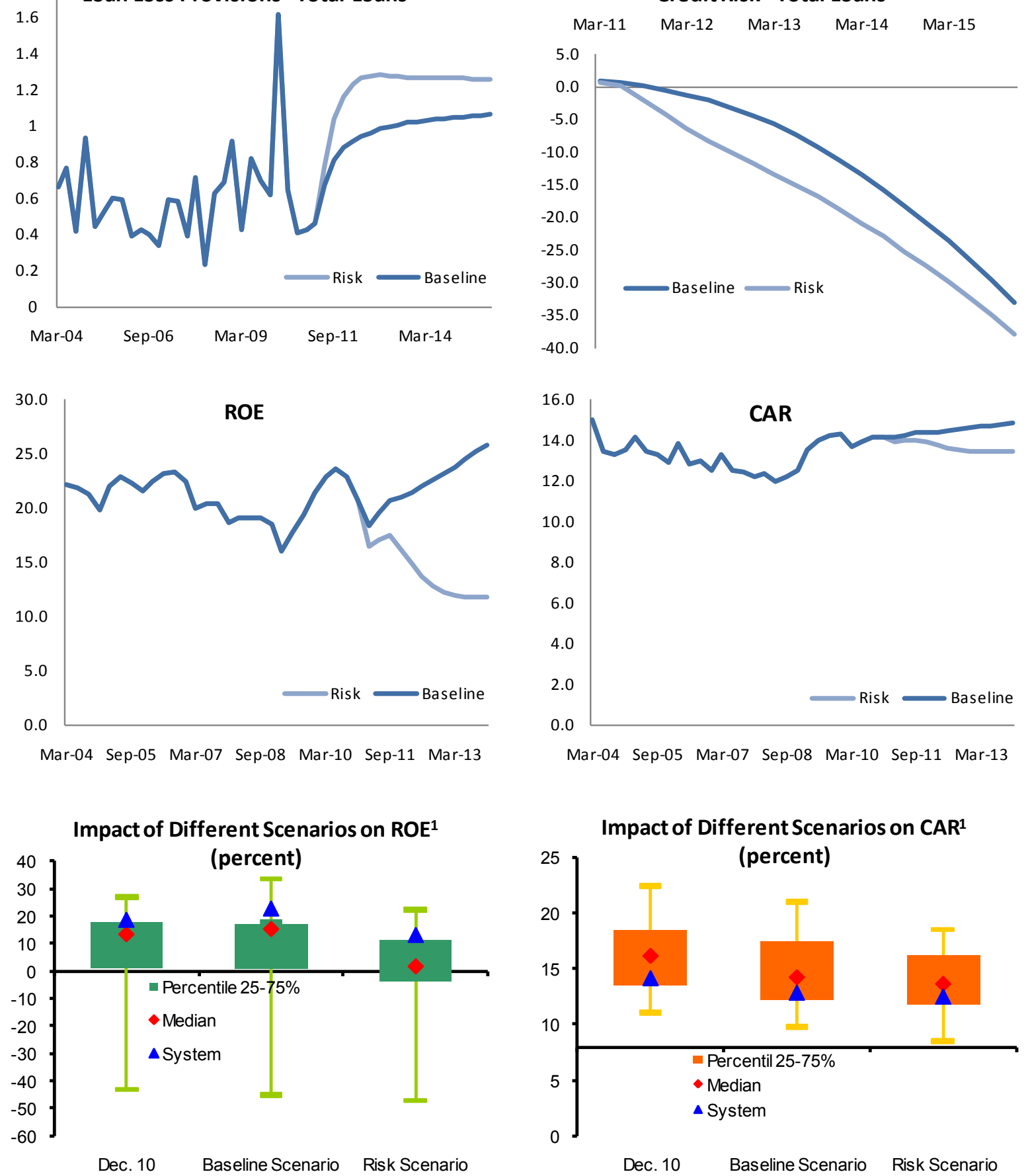

${ }^{1}$ ROE is weighted by the Tier 1 capital of each institution. Source: BCCh. 
Table 3. Chile: Market Risk

(percent of Tier 1 capital)

\begin{tabular}{|c|c|c|c|c|c|c|c|}
\hline \multirow{2}{*}{ Cluster } & \multirow{2}{*}{$\begin{array}{l}\text { Market } \\
\text { Share }^{1}\end{array}$} & \multicolumn{2}{|c|}{ Interest Rate } & \multicolumn{2}{|c|}{ Exchange Rate } & \multicolumn{2}{|c|}{ Market Risk } \\
\hline & & Baseline & Risk & Baseline & Risk & Baseline & Risk \\
\hline Large Banks & 66.7 & 0.60 & -0.63 & 0.00 & 0.00 & 0.60 & -0.63 \\
\hline Medium Banks & 28.5 & -0.45 & -4.17 & -0.02 & -0.23 & -0.48 & -4.40 \\
\hline Small Banks & 1.2 & -0.66 & -2.83 & 0.00 & 0.00 & -0.66 & -2.82 \\
\hline Treasury Banks ${ }^{2}$ & 3.6 & -1.24 & -4.98 & 0.00 & 0.00 & -1.24 & -4.98 \\
\hline System & 100.0 & 0.27 & -2.10 & 0.00 & 0.00 & 0.27 & -2.10 \\
\hline
\end{tabular}

Source: BCCh.

${ }^{1} \%$ of total assets.

${ }^{2}$ Banks that are dedicated to investment in derivative and nonderivative financial instruments and that do not have loans.

12. The system was also tested for severe funding and market liquidity shocks, and the closing of funding markets. ${ }^{7}$ The exercises included a sudden, substantial withdrawal of funding (see Box 2); and tests to assess maturity mismatch and roll-over risk, and banks ${ }^{6}$ ability to meet the new Basel III liquidity ratios. The analysis illustrates that most banks are able to cope with major liquidity shocks. Most banks (in terms of assets) are yet to meet the LCR, although the liquidity shortfall appears manageable (see Box 1 for details), while all but two banks already meet the NFSR, pointing to limited structural maturity mismatches in Chilean banks.

\section{B. Institutional Investors}

\section{Annuities and Earthquake Insurance}

13. The solvency of life insurance companies has improved as a result of changes in retirement qualification rules and the effects of recent losses in pension portfolios. Chile is an international outlier in that the balance sheets of life insurance companies are dominated by annuity obligations (close to 90 percent of liabilities). A series of reforms in 2004 effectively encouraged later retirement by tightening the parameters that defined eligibility for early retirement. The losses incurred in AFP-administered portfolios as a result of the recent global crisis further reduced the incentive to retire early. The resulting deferral of retirement - which is still working its way through the system-has lowered the longevity risk profile of the annuitant pool (it now is closer to that of the average population) and hence enhanced the solvency of life insurance companies. The financial position of these companies further strengthened as a result of stricter provisioning rules.

\section{By investing in long-dated illiquid assets, annuity providers can achieve higher} yields while limiting increases in credit risk exposure. The conventional investment

\footnotetext{
${ }^{7}$ See Schmieder, Hesse, Pihr, Cihak, and Hasan (2011), - Second Generation Stress Testing—Methodological Framework for Liquidity Risk Tests," IMF Working Paper.
} 
approach that matched annuity (long-term and fixed interest rate) liabilities with long-term government bonds became impractical as the annuity pricing rate has exceeded the bond rate since 2001. In response, emphasis was first shifted to fixed-rate corporate bonds to capture higher yields, which helped develop the now large domestic bond market. More recently, insurers have shifted around 7 percent of their portfolio into local real estate-related assets that are perceived to have limited credit risk but are highly illiquid, and to foreign corporate fixed income securities. This move has enabled life insurance companies to seize higher yields (by capturing of the illiquidity premium) while diversifying credit and counterparty risk. Nonetheless, the securities and insurance superintendence (SVS) will need to monitor real estate-related asset structures and values more closely due to their bespoke nature.

15. The performance of insurance companies and the SVS in the context of the major earthquake and associated tsunami of February 2010 was impressive. The country suffered extensive destruction of property, and the insurance industry settled 98 percent of the claims within seven months following the earthquake. Losses to local insurance companies were limited as the associated risk had been transferred to international markets via reinsurance. The SVS played a proactive role in informing homeowners of their insurance coverage and in monitoring the settlement and payment of property claims.

\section{Pension Funds' Asset Allocation}

16. There have been important improvements in pension funds' risk diversification since 2004. Investment portfolios are better diversified following changes in investment limits (including a higher allowance for foreign investments), and are now more in line with the long-term objectives of the system. ${ }^{8}$ Investment regulation has been simplified in the 2008 reform and draft legislation would increase flexibility further, including by letting pension funds invest directly in foreign currencies and participate in financial restructuring processes. A basic pension safety net (a Pillar 1) was also introduced in 2008 to complement the funded pension system, particularly for low-income wage earners, thereby allowing pension funds to take a little more risk for the purpose of long-term return optimization.

\section{Lower real returns in the future may lead to insufficient replacement rates and} may require higher contribution rates and retirement age as well as lower costs. The average historic real return on the system portfolio since inception has been above 9 percent, but the trend is downward (12 percent in the first decade, 9 percent in the second, and 6 percent since 2000). Going forward, achieving long-term real returns in the 6 percent range may prove challenging. In such circumstances, even members with consistent contributions through their working life (high contribution density) may face problems in reaching a 70 percent replacement rate with only 10 percent contributions on wages. This may require

\footnotetext{
${ }^{8}$ The pension fund system offers five different investment portfolios with different risk-return profiles; the most aggressive portfolio for the younger contributors holds 80 percent in equities and 70 percent abroad.
} 
higher contribution rates and/or retirement ages, and under such circumstances pressures on AFPs to reduce costs may increase. ${ }^{9}$

\section{High foreign holdings make the regulation of hedging essential from a macro} stability point, and proposed legal changes point in the right direction. Presently around 45 percent of AFPs' foreign positions must be hedged. Due to the large size of AFPs and of their combined foreign holdings, pension funds must hedge the equivalent of around 15 percent of GDP. Draft legislation would move the regulation of hedging from the law to the investment regime, giving more flexibility to SP to regulate the issue with inputs from the Technical Investment Committee, the ministry of finance, and the central bank. Any change in hedging regulations should consider the implications for the foreign exchange market.

\section{Financial Sector Oversight}

\section{A. Sectoral Issues}

\section{Banks}

19. Chile has made steady progress in enhancing its already robust bank supervisory framework. Risk-based supervision is grounded on a well defined bank rating system, set in the law and regulation. The regulation and supervision of liquidity and market risks was strengthened by defining minimum requirements for bank policies, establishing a limit for market risks in the trading book, issuing a regulation on derivatives, improving the measurement of liquidity risks by moving to a financial cash flow model of income and expense maturity gaps, establishing stress testing requirements, authorizing the use of internal models, and improving disclosure. A new provisioning regime is in effect since January 2011. The new standards for accounting and financial information, issued in 2009, follow International Financial Reporting Standards (IFRS). The SBIF has also published for public consultation a draft norm on corporate governance that adopts the principles for corporate governance recently issued by the Basel Committee on Banking Supervision.

20. The new provisioning regime is a step toward improving risk management. The regulation establishes one standard model for debtors assessed individually based on explicit parameters on expected losses and with a minimum provisioning requirement of 0.5 percent of performing commercial loans; and two options both based on banks' internal models for debtors assessed as a group. In addition, the new voluntary countercyclical additional provisions, also based on internal models, are intended to enhance banks" protection against unexpected idiosyncratic shocks. Chile's new provisioning norm is at the forefront of international practice and should serve the banking system well. With time, the following

\footnotetext{
${ }^{9}$ AFPs ' profitability is high relative to the risk they take and, after 30 years of operation, they still charge explicit fees equivalent to 60-70 basis points on assets under management.
} 
improvements could be considered: (i) introducing two options for loans assessed both individually and as a group - a standard approach based on minimum parameters defined by SBIF, and an internal models approach subject to prior approval by SBIF; (ii) establish SBIF guidelines for estimating the cyclical component provisions, including general criteria for setting accumulation and draw-down triggers; and (iii) consider countercyclical tools calibrated on the financial cycle to address systemic risks.

\section{Legal amendments have strengthened supervisory capacity but key issues}

remain to be addressed. Recent improvements include: the tightening of requirements for bank shareholders; information sharing among supervisors; and access by SBIF to information on bank affiliates. Key legal issues that are yet to be addressed are: changes to the general banking law to allow for full implementation of Basel II and III capital requirements; conglomerates supervision; system-wide oversight; and resolution framework (the last three issues are discussed in special sections). Additionally, fit and proper requirements for bank directors and managers need to be further specified along the lines of those recently established for shareholders.

\section{Current institutional arrangements provide limited independence and legal}

protection to bank supervisors. The Superintendent is appointed by the President of Chile, has no fixed term of appointment, and may be dismissed by him without cause. The law specifies that the SBIF relates with the government through the ministry of finance. Its budget is part of the general government budget. While SBIF staff is highly qualified and well respected, their salaries are not competitive with the industry and turnover is high. An amendment to the banking law stipulates that SBIF is to provide legal assistance to the Superintendent, even after ceasing his duties, but this falls short of international best practices when it comes to the legal protection of the Superintendent, SBIF, staff and other SBIF agents (interventors and provisional administrators). Such practices include the provision of indemnity - from personal and institutional liability — for all acts taken by the employee in good faith and in the discharge of duties under the relevant laws.

\section{Capital adequacy requirements follow Basel I standards, complemented with} elements of Basel II and III. There are no capital charges for market or operational risk, but exposures to market risks are subject to a limit based on the 1996 amendment of the Basel I Capital Accord. SBIF now publishes capital adequacy ratios for all banks, adjusted by their market risk exposures. Some elements of Pillars 2 and 3 of Basel II are already part of the supervisory processes, including the supervisory assessment of capital and disclosure requirements. The legal framework also contains elements of Basel III, such as the leverage ratio (capital has to be higher than 3 percent of total assets) and a systemic capital surcharge. ${ }^{10}$ The authorities are working to adopt the main elements of Basel II and III.

\footnotetext{
${ }^{10}$ A higher capital adequacy ratio (from 10 to 14 percent) is temporarily required (for no less than one year) when a merger or acquisition would result in a bank with a market share above 15 percent.
} 


\section{Insurance}

24. Weaknesses in life insurance oversight identified in the 2004 FSAP have been reduced significantly (see Annex). Mortality tables have been updated and are now regularly reviewed to provide for future life expectancy improvements. As noted earlier, the change to the profile of annuitants has also moderated the mortality risk to which life insurance companies are exposed. The SVS should take advantage of solvency improvements in life insurance companies to shorten the transition (forbearance) period for the upward adjustment in capital to the levels required by the updating of the mortality tables.

25. The insurance industry and SVS are adapting to a significant wave of legal and regulatory reforms, including the introduction of a risk-focused approach. Draft amendments to the Insurance Law to be presented shortly to Congress will bring into effect a comprehensive system of risk-based supervision accompanied by a new standard of minimum solvency for insurance companies along the lines of Solvency II. SVS has already made significant progress to prepare risk-based approaches but the approval of the proposed legal amendment is necessary to remove the remaining constraints. As insurance companies are typically part of financial groups, the effectiveness of such a move to a risk-focused approach would be substantially boosted if, as recommended below, Chile also moves resolutely toward the consolidated oversight of financial conglomerates.

26. There is considerable room to enhance the relevance of the actuarial profession, which would lead to significant gains in the integrity of insurance markets. Serious efforts should be devoted to developing a strong independent actuarial profession. Among other things, a stronger actuarial profession would take a lead role in the selection of assumptions for the pricing and valuation of annuity liabilities.

\section{Securities}

27. The regulation of securities markets in Chile has strengthened significantly in recent years. The assessment of implementation of the IOSCO Objectives and Principles of Securities Regulations documents a large improvement with respect to the 2004 assessment. Further improvement will require augmentation of the authority and powers of the SVS in critical areas of broker regulation (notably resolution of a failing brokerage firms) and in its ability to investigate and enforce compliance with the law. In this regard, the SVS is already promoting legal changes that would allow it to bypass secrecy provisions when investigating breaches of the securities markets law. These issues are discussed in further detail in the Report on Implementation of Standards and Codes for the IOSCO Principles (see Annex).

\section{Anti-Money Laundering}

28. Chile has made progress in developing its AML/CFT framework, but further work is needed to strengthen it. The Financial Action Task Force (FATF)-style regional body for South America, GAFISUD, conducted a mutual evaluation of Chile's AML/CFT 
regime against FATF's recommendations in 2010. ${ }^{11}$ The key highlights are that the laws criminalizing the money laundering and terrorism financing offenses should be amended to be fully consistent with international standards, and there is scope to improve their implementation. There should also be a clear legal obligation for reporting entities to report suspicious transactions related with the financing of terrorism.

29. The AML/CFT preventive measures in the financial system are still evolving and there is a need to improve their effective implementation. The absence of regulation and supervision of the currency exchange bureaus is a significant deficiency that creates a systemic money laundering and terrorism financing vulnerability. While supervisory agencies have the capacity to apply sanctions for failures to comply with AML/CFT obligations, few sanctions have been applied to date.

30. While Chile has signed and ratified the relevant international conventions, there is still a need to strengthen the system in the area of international cooperation, by removing the legal obstacles to sharing information subject to secrecy provisions and enacting provisions governing requests for mutual legal assistance in the area of asset forfeitures for cases where there is no treaty.

\section{B. System-Wide Oversight}

\section{Consolidated Oversight}

31. Since the 2004 FSAP, steps have been taken to improve the supervision of financial conglomerates (FC). Amendments to the banking law granted SBIF the power to request and access all information on subsidiaries of banking institutions, and authorized the three financial regulators (SBIF, SP, and SVS) to share information with the exception of that subject to banking secrecy. The Committee of Superintendents, which includes the central bank as an invited member, meets on a monthly basis, though it lacks a legal basis. A technical secretariat of this committee was established in November 2008 to facilitate coordination. Since then, the committee has worked to improve the knowledge of financial conglomerates and some cross-sector regulation has been issued.

32. In spite of progress and the built-in firewalls to protect supervised institutions (such as related-party exposure limits), lack of a comprehensive oversight framework for FCs could leave significant risks overlooked and without adequate cover. The main challenge is to adequately monitor the risks for the domestic FCs - some of which could be considered systemic — stemming from the unregulated, nonfinancial, and cross-border

\footnotetext{
${ }^{11}$ This was GAFISUD‘s third mutual evaluation of Chile.
} 
parallel entities. ${ }^{12}$ These blind spots could facilitate double gearing and create opportunities to hide solvency problems of the financial and mixed conglomerates. Additionally, the resolution framework does not have arrangements suitable for managing the failure of a FC (see next section).

33. Consolidated supervision of FCs could be implemented in two phases. The first phase would intensify efforts under the current legal framework (Box 3). The second one would imply major legal reform to establish a comprehensive framework for consolidated supervision. Further efforts under the current legal framework would mitigate some of the risks, but effective control of risks would not be achieved unless the blind spots are eliminated under a reformed legal framework.

34. The essential building blocks of a reformed legal framework to enable the consolidate oversight of FCs include the following: (i) an explicit definition of FC, common to all domestic supervisors; (ii) a clear allocation of powers and responsibilities for consolidated supervision of the FC; (iii) access to information on all operations of the wider financial group on a consolidated and individual basis, as well as on all nonfinancial entities of the group; (iv) the capacity to identify a de facto FC for consolidated supervision purposes (using presumption if needed); (v) prior authorization requirement to establish abroad any financial institution part of the FC and to undertake investments or transfers of ownership that would affect the capacity to conduct effective supervision or entail new material risks; (vi) requirement that the local FC with cross-border parallel operations or with structures not suitable for consolidated supervision take corrective action; (vii) capital adequacy, liquidity, corporate governance, risk management, and disclosure requirements, and limits on large and connected party exposures, all at the level of the FC; and (viii) a corrective action framework to address compliance with the above framework.

\section{Leveling the Playing Field in Financial Services Oversight}

\section{Regulation in Chile is not uniformly robust across all sectors of the financial} services industry, and there is significant scope for leveling the playing field. While banks, brokers, mutual funds, insurance companies, pension funds, investment advisers, and other nonbank financial institutions frequently are in direct competition and offer comparable products and services, they are not subject to uniform regulation. Gaps and inconsistencies in financial services oversight create scope for regulatory arbitrage. Regulators should use their existing powers to improve uniformity; in some cases, legislative initiative might be required. Achieving a level playing field in financial regulation will require a number of steps.

\footnotetext{
${ }^{12}$ Responsibility for consolidated supervision of foreign controlled FCs rests with the home supervisor. Cooperation arrangements are in place in the form of MoUs and are being used effectively.
} 


\section{Box 3. Consolidated Supervision: Further Efforts under the Current Legal Framework}

Further efforts under the current legal framework would aim to achieve the best possible understanding of the FC risk profile, by establishing de facto lead supervisors for each FC and improving information access and exchange. The short-term actions would include the following:

- Sign a new MoU to clearly define the roles of lead and sector supervisors. The lead supervisor for each FC would be the supervisor of the entity with the largest share in the conglomerate assets (or liabilities);

- Define the information flows between lead and sector supervisors. The lead supervisor would receive sectoral details that would be used to prepare the overall risk profile of the conglomerate. Sector supervisors, in turn, would receive the overall risk profile;

- Use current powers of supervisors and the central bank to improve the coverage of information on unregulated parts of the group (e.g., nonfinancial issuers, retail credit card operations) regularly and on a timely basis;

- Improve cooperation and information exchange with host supervisors of cross-border parallel establishments;

- The lead supervisors would use the additional information gathered to estimate proxies of the capital and risk concentrations of the FC;

- The lead supervisor would assemble a (provisional) report on the risk profile of the FC, on the basis of the best information available. This report would have to focus on overall solvency and risks, by examining interconnections, linkages, and concentrations;

- The risk profile should also identify the scope of the de facto FC and the remaining information gaps;

- These risk profiles would be use to design the supervisory strategies for each FC, using the powers over the main supervised members to communicate the supervisory concerns and expected actions; and

- Once the planned amendments of Basel II Pillar 2 (and Solvency II) are in place, the lead supervisors could require additional capital charges, reflecting group-wide risks, to the main supervised member of the FC. The effectiveness of these capital requirements would be hampered by severe information restrictions.

\section{All persons and entities providing comparable investment services to the public} should be subject to consistent regulation. Significant differences exist among the three regulatory agencies in the regulation of comparable activities, including, for example, customer investment suitability standard, internal controls requirements, disclosure of fees and expenses, and qualification processes. ${ }^{13}$ Moreover, while SBIF may take control of a failing bank and SVS may take control of a failing mutual fund or insurer, SVS (or any other regulator) cannot take action if a broker fails.

\section{Increased uniformity with respect to financial infrastructure would bring} benefits in terms of both cost reduction and lower systemic risk. Chile has developed a central counterparty system for clearance and settlement of transactions and a national custodian of securities. Use of the central counterparty, CCLV, and the third-party depository, DCV, is mandatory for brokers, mutual funds, pension funds, and insurers, but is

\footnotetext{
${ }^{13}$ The accreditation process envisioned to be implemented this year should include such requirements.
} 
voluntary for banks. The authorities should consider an approach to this field that harmonizes the trading requirement of securities irrespective of the entities trading them. ${ }^{14}$

\section{The extent to which retailers' credit cards operations should be brought within} the perimeter of regulation requires careful consideration (Box 4). In Chile, an important share of credit cards services is in the hands of nonbank issuers that are part of mixed (department store) conglomerates. Nonbank issuers can leverage and fund their operations by borrowing from banks. Beyond a minimum absolute capital, they are subject to prudential requirements only to the extent that outstanding obligations with non-related businesses are not settled in three days or less, a condition that none of the existing issuers fulfill. Enhanced monitoring of these issuers is highly advisable, to gauge in particular their degree of leverage and the risks posed to the conglomerate, in terms of credit, contagion, and reputational risk. More generally, the potential emergence of high leverage outside the perimeter, which is possible under the current legal framework, needs to be closely monitored.

\section{Policy Coordination and System-Wide Oversight}

39. The authorities have a keen interest in strengthening the framework for coordination of financial policies, including arrangements for systemic oversight. An independent commission was asked in August 2010 to examine the structure of financial oversight and consider reforms in light of lessons from the global crisis. The Commission's recommendations, which were published in April 2011, include moving toward a twin peaks" regulatory structure while enhancing the independence and accountability of regulators; establishing a Financial Stability Committee to identify and act upon systemic risks; and formalizing the committees in charge of regulatory coordination and financial sector development. The ministry of finance has since endorsed the creation of a Financial Stability Committee and the conversion of SBIF and SVS into commissions (without moving to a twin peaks approach). The Financial Stability Committee was established by Presidential decree in July 2011.

40. The establishment of the Committee is a welcome step but caution will be needed to ensure that it can discharge its functions effectively. The Committee will monitor system-wide risks and recommend policy measures in support of financial stability; it will also coordinate actions in the event of systemic crises. The Committee is chaired by the ministry of finance and includes the supervisory agencies as members; for legal reasons, the central bank participates as an observer. Because the BCCh can bring important expertise to the Committee in monitoring the financial system and discussing policy actions, in its role as observer it should be able to adequately influence the Committee's decisions, while preserving its independence.

\footnotetext{
${ }^{14}$ At present when a security is traded by a pension fund, mutual fund, or a brokerage firm it has to be traded in an exchange, but if the same security is traded among banks it can be traded OTC, with less transparency.
} 


\section{To preserve regulatory autonomy, the Financial Stability Committee should delegate all institution-specific issues to a sub-committee of supervisors (except in times} of systemic crisis). A key responsibility of this sub-committee would be to coordinate the supervision of financial conglomerates, keeping in mind that strengthening coordination arrangements among supervisors will not by itself provide the necessary legal framework for the conduct of consolidated supervision.

\section{Box 4. Regulatory Treatment of Credit Cards}

The number of credit cards in circulation at end-2010 reached almost 30 million — significantly larger than Chile's population of 17 million - and there were 290 million individual transactions for a total dollar amount of US\$ 21 billion. This market represents an important source of credit for Chilean consumers.

While credit cards issued by banks and retailers capture similar market shares in dollar terms, retailers issue over three times as many cards and retail credit cards account for almost 70 percent of transactions.

As this market grows and more people gain access to credit, there is growing concern about the different regulatory treatment of credit card issuers. Specifically, banks and cooperatives that issue credit cards must be included in the Credit Card Issuer and Operator Register maintained by the SBIF and are subject to all relevant prudential regulation. Nonbank issuers on the other hand, while also required to enroll the Registry, are subject to lighter regulation. The current regulatory treatment seeks to minimize risks imposed by credit cards on the payment system, which is addressed by settlement time requirements. Specifically, nonbank issuers responsible for payments to non-related businesses exceeding UF 1 million that

Credit Cards Transactions, 2010

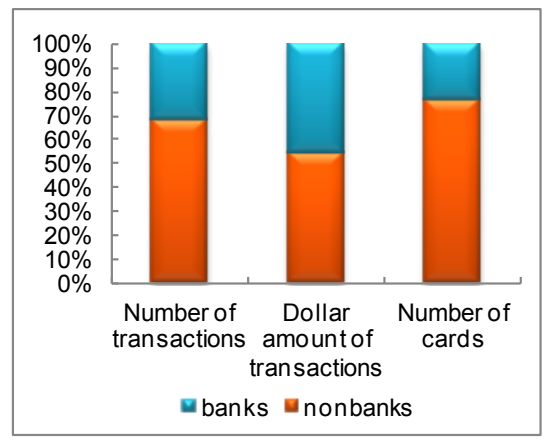
agree to settle obligations in...

\begin{tabular}{|l|l|}
\hline \multicolumn{1}{|c|}{....less than 3 working days must: } & \multicolumn{1}{|c|}{...more than 3 working days must: } \\
\hline $\begin{array}{l}\text { Include issuance of credit cards in their business } \\
\text { purposes. }\end{array}$ & $\begin{array}{l}\text { Declare issuance of credit cards and related activities as } \\
\text { their sole business purpose. }\end{array}$ \\
\hline Maintain capital and reserves of no less than UF 100,000. & $\begin{array}{l}\text { Maintain capital and reserves of no less than UF } 200,000 . \\
\text { Total obligations cannot exceed } 12.5 \text { times capital and } \\
\text { reserves. }\end{array}$ \\
\hline $\begin{array}{l}\text { Maintain liquid assets equivalent to obligations maturing } \\
\text { within } 30 \text { days, consisting of cash, checking accounts held } \\
\text { in domestic banks, deposits with maturity of less than } 90 \\
\text { days, or debt instruments issued by the BCCh or the } \\
\text { ministry of finance. Total liquid assets must be greater than } \\
\text { percent of total obligations. }\end{array}$ \\
$\begin{array}{l}\text { Present an annual risk management report to SBIF } \\
\text { audited by an entity registered with SBIF. }\end{array}$ & $\begin{array}{l}\text { Adhere to operational, informational, and credit and } \\
\text { liquidity risk norms established by SBIF. In addition, SBIF } \\
\text { may require an audited annual report regarding these areas. }\end{array}$ \\
\hline $\begin{array}{l}\text { Nonbank issuers not included in the above cases must report yearly total payments to SBIF. Issuers with } \\
\text { payments above UF 750,000 can opt, but are not mandated, to enroll in the register and adhere to the norms. }\end{array}$
\end{tabular}




\section{Safety Nets and Crisis Preparedness}

\section{The framework for crisis management and resolution would benefit from a}

number of enhancements. While resolution authority for insurance companies and mutual and pension funds appears adequate, authority to intervene brokerage firms should be established. With regard to bank resolution, the priority should be to enhance powers to address the idiosyncratic failure of individual banks. Second order priorities would include setting up a framework to address systemic banking problems - which could be established at the time of the planned implementation of Basel III capital buffers for systemic institutions, ${ }^{15}$ and considering the introduction of arrangements to address the resolution of a FC. The recent crisis simulation exercise will be an opportunity to investigate areas for further improvement in the legal framework and to design a strategy for crisis preparedness.

\section{In the mission's view, a number of legal reforms would be critical to enhance the effectiveness of the bank resolution framework:}

- $\quad$ Broaden the available set of resolution tools, including purchase and assumption (P\&A) transactions; ${ }^{16}$ good bank/bad bank; bridge bank to allow for a rapid and lower cost resolution; the ability to undertake a recapitalization without the preemptive rights of shareholders; and the ability to undertake a forced bank debt restructuring.

- Grant SBIF the powers to write down capital as part of a bank restructuring. The law could preserve shareholders' rights by establishing an appeal process (without suspension or reversal of the decisions). Currently, shareholders' equity can be diluted via asset sales by the provisional administrators and via a capital increase, which the authorities see as equivalent in practice.

- $\quad$ Strengthen the legal protection of officials in charge of resolution (the provisional administrator and the liquidator), along the lines of what recommended for supervisors.

\section{The authorities should also consider introducing a premium-based partial} deposit insurance in lieu of the current partial government guarantee on time deposits. Deposit insurance funds could be used not only for the payment of depositors during

\footnotetext{
${ }^{15}$ Such a framework might include: (i) determination of the $\rightarrow$ sstemic risk" should be carried out by a credible committee (such as the new Financial Stability Committee); (ii) lifting the legal obstacles for the use of public funds in systemic cases; (iii) making explicit that the use of public funds would be authorized after an analysis of the alternative costs, provided that this represents the least cost for the tax payers; and; and (iv) establishing a mechanism for ex-post accountability.

${ }^{16}$ Currently, some carving out of assets is allowed. For instance, mortgage bonds can be carved out along with the underlying mortgages, and the provisional administrator can sell up to 50 percent of assets and liabilities at his/her discretion.
} 
liquidation, but also to facilitate implementation of the resolution options, including good bank/bad bank, P\&A transactions, and the bridge bank. The use of deposit insurance funds for resolution could be allowed on a less-cost basis, that is, provided that the funds to be used are lower than insured deposits net of estimated asset recoveries during liquidation.

45. The central bank sight deposit guarantee serves the double purpose of protecting the payment system while at the same time protecting some depositors. In this regard, the authorities could assess the pros and cons of phasing out this feature of the safety net, in the context of establishing partial deposit insurance, strengthening the resolution framework, and introducing Basel III systemic capital charges. 


\section{AnNex I: ObSERVANCE OF FinANCIAL SECTOR STANDARDS AND CODES SUMMARY ASSESSMENTS}

The annex contains summary assessments of four international standards relevant for the financial sector. The assessments were undertaken in the context of the FSAP and have helped identify the extent to which the supervisory and regulatory framework is adequate to address the potential risks in the financial system in Chile.

The following detailed assessments of financial sector standards were undertaken:

- The IAIS Insurance Core Principles (ICP), by Donald McIsaac (insurance expert from Canada); and

- The IOSCO Objectives and Principles of Securities Regulation, by Jonathan Katz (securities expert from the United States).

\section{A. Observance of the IAIS Insurance Core Principles}

\section{Information and methodology used for the assessment}

46. This assessment benchmarks Chile's regulatory regime against the 2007 version of the ICPs. ${ }^{17}$ The assessment covers all regulated entities licensed by the SVS. The previous 2004 FSAP did not perform an assessment against the ICP. The assessment was made on the basis of a study of the legal and regulatory framework, ${ }^{18}$ a self-assessment and details in response to an extensive advance questionnaire by SVS, and detailed discussions with relevant authorities and stakeholders. Discussions were held with government representatives, SVS staff, representatives of the trade association, and executives of major companies, both life and general insurance companies, operating in the market. Other contacts included insurance and reinsurance brokers, auditors, and members of the local institute of actuaries.

\section{Institutional and macroprudential setting}

47. SVS has responsibility for licensing and supervision of all players in the insurance market, such as insurance companies, sales personnel (mainly insurance brokers although there are some agents), loss adjusters, reinsurance companies, and reinsurance brokers. SVS has a special partnership with SP in respect of the supervision of insurance companies' life annuity business. In addition to its role as a supervisor, SVS is also responsible for preparing laws and regulations applicable to the insurance industry, even though it lacks the authority to enact regulations. That power rests with the cabinet and the ministry of finance.

\footnotetext{
${ }^{17}$ The 2007 version is the latest version available to the public at the time of the mission. A newer version is under development and may be adopted by IAIS before the end of 2011.

${ }^{18}$ SVS maintains a comprehensive website with all laws and regulations applicable to insurance companies in Chile. Also available are all guidelines of general application to the insurance companies, comprehensive statistics on the industry, and copies of annual and quarterly SVS reports. The website is also used as vehicle for distributing discussion drafts of proposed changes in the regulatory system or drafts of forthcoming guidelines.
} 
48. Chile has one of the most mature insurance markets and the highest insurance penetration, measured as premium to GDP, for Latin America. Total premium to GDP stood at 4 percent for 2009 with 2.6 percent for life insurance and 1.4 percent for non life insurance segments. Over the medium term, growth in both real and nominal terms has been sound and the sector has generated increased premium per capita. Though with some volatility, insurance penetration has doubled in the last 25 years. This growth was achieved through the progressive development of the market, both in life and non-life segments, and the maturing impact of the pension system reforms, including an increasing demand for life annuities.

49. There were 58 insurance companies operating in Chile (32 life and 26 general insurers) as of September 2010, with a balance between foreign and local insurers. The trend has shown an increase after a period of some consolidation. The market is highly competitive, with the Herfindahl index standing below 1,000 in both life and non life segments. ${ }^{19}$ Product pricing and distribution competition is fierce in both life and non-life markets, particularly for annuities where money's worth ratios have been generous, and have remained so for a number of years. Currently, 12 of the life insurers and 15 of the general insurers are controlled by foreign insurance groups, and foreign interests provide 36 percent of industry capital in the life sector and 68 percent in the non-life sector. Premium income by foreign insurers represents 50 percent for the life sector and 66 percent of the non-life sector as of September 2010. As part of the development of risk-based approaches, the mix of local and foreign insurers is likely to be an asset to the sector.

\section{Planned changes to the regulatory framework}

50. The 2004 FSAP conducted a review of the insurance sector that, among other things, recommended a move to a more risk-based approach to supervision. The SVS took up this initiative, seeking the assistance of other supervisors with experience in risk-based supervisory approaches, including SBIF, and experiences from Canada and Europe. A White Paper" on the New Model of Supervision was published for discussion with the industry in $2006 .{ }^{20}$ In line with the most pragmatic implementation approaches, several initiatives taken were oriented internally to SVS. These included the reorganization of supervisory teams to refocus resources and create a specialist risk-oriented group, developing an internal ratings approach, training of supervisory staff, elaboration of supervisory manuals, and pilot testing of the approach with a subset of the industry.

\footnotetext{
${ }^{19}$ For a full discussion on the comparative benchmarking of the Herfindahl index and the assessment of the level of the index, see Thorburn, (2008), Insurers: Too Many, Too Few, or “Just Right”? Initial Observations on a Cross-Country Dataset of Concentration and Competition Measures, World Bank Working Paper 4578.

${ }^{20}$ SVS, 2006, Nuevo Modelo de Supervision de Solvencia Basada en Riesgos para la Industria Aseguradora Chilena (December), http://www.svs.cl/sitio/mercados/doc/white_paper_espa06.pdf.
} 
51. SVS has made considerable advances but is now in a position where further progress is restricted by current legislation. Many recent regulatory initiatives have been accomplished through guidelines since they appear to be simpler to enact and impose. This risks creating a dual system where sector players must comply with both the laws and the guidelines. To secure the next phase, with the engagement of the insurance sector more completely, it is appropriate and necessary to make some legislative adjustments.

52. To some extent, the insurance law has already suffered from a -empliance creep" problem. For example, although well designed and appropriate for the time, the calce rule was not able to respond to all the challenges presented by changing market conditions and an additional financial obligation had to be added. ${ }^{21}$ The successive addition of obligations now makes the financial regulation of capital and solvency for the insurance sector in Chile one of the most complex and opaque in the world. The absence of a modern approach to capital regulation that fits within a risk-based supervisory approach has prevented taking a more flexible approach.

53. In response to this challenge, SVS and the ministry of finance have developed proposals for legislative amendments to facilitate the next phase of the risk-based supervision initiative. In essence the new system will employ a two-part assessment of the financial strength of companies. Based on its assessment of a company's circumstances, SVS will apply to each company a rating using a variety of information - such as financial returns, onsite inspections, and industry intelligence. At the same time, companies will receive a second ranking developed from the relationship between its available capital-and-surplus and the amounts determined to be required according to the risk-based capital formula. Senior SVS staff will discuss the combination of these two tests with company management. Depending on circumstances, SVS could demand remedial action by management, or could apply sanctions against the company. These new tools, supported by legislation, should enable SVS to act more swiftly when dealing with problem situations.

54. SVS has issued a draft guideline on corporate governance, following a study of best practices in corporate governance for insurance companies. Comments have been invited from industry participants and it is expected that the guideline will be adopted in 2011. The guideline will impose responsibilities which some Chilean directors will find new and different. The guideline makes clear that directors have a responsibility to develop policies for the management of the companies and for the oversight of management to ensure that those policies are being followed. The guideline speaks specifically to the important risks that an insurance company faces (e.g., investment risk, underwriting risk, and management risk) and indicates that the supervisor will be reviewing the performance of management in dealing with these risks and the actions of directors in monitoring that performance.

\footnotetext{
${ }^{21}$ The reserve regulations in Chile, generally referred to as calce rule, impose larger technical reserves the greater the duration mismatch.
} 
55. SVS has also issued a new draft guideline for general (non-life) insurance companies, providing more detailed specifications in the area of reserving. This guideline will shortly be distributed to the industry for discussion. Draft legislation, to be presented to Congress in the near future, includes a proposal for the adoption of risk-based capital as a solvency measure. SVS is currently engaged in the development of an appropriate formula for such purposes. As experience in other countries has shown, it will be necessary to ensure that the risk weights and other factors adopted for solvency measurement in Chile are appropriate for the conditions in Chile's insurance market.

\section{Main findings}

56. SVS carries out its supervisory responsibilities in an effective manner, demonstrated by the fact that insurer failures and insolvencies are rare. The only such event in recent memory occurred because problems in an affiliated company within a conglomerate led to the closure of an insurance company. As has been noted elsewhere, the regulatory system itself is in need of some overhaul. New legislative proposals that will lead to a risk-based approach to supervision will be of considerable assistance as will the enhanced powers of intervention that should be available to the supervisor under the new approach.

Table 4. Chile: Summary Observance of the IAIS Core Principles

\begin{tabular}{|c|c|}
\hline Insurance Core Principles (ICP) & Comments \\
\hline $\begin{array}{l}\text { Conditions } \\
\text { ICP1—conditions for effective insurance } \\
\text { supervision }\end{array}$ & $\begin{array}{l}\text { Need to strengthen the role and professionalism of both } \\
\text { auditors and actuaries. Local professional bodies should } \\
\text { set their own technical and ethical standards. }\end{array}$ \\
\hline $\begin{array}{l}\text { The Supervisory System } \\
\text { ICP2-Supervisory objectives } \\
\text { ICP3-Supervisory authority } \\
\text { ICP4-Supervisory process } \\
\text { ICP5-Supervisory cooperation and information } \\
\text { sharing }\end{array}$ & $\begin{array}{l}\text { Improvement is required in three areas: intervention } \\
\text { powers of supervisor, legal protection for supervisory } \\
\text { staff, and information sharing with other supervisors }\end{array}$ \\
\hline $\begin{array}{l}\text { The Supervised Entities } \\
\text { ICP6-Licensing } \\
\text { ICP7-Suitability of Persons } \\
\text { ICP8 - Changes in control and portfolio transfers } \\
\text { ICP9 - Corporate governance } \\
\text { ICP10 - Internal Controls }\end{array}$ & $\begin{array}{l}\text { SVS has limited authority to impose conditions on the } \\
\text { license granted to an insurance company and to apply -if } \\
\text { and proper" requirements in judging key personnel; } \\
\text { corporate governance requires strengthening, but this } \\
\text { should be achieved with new legislation and guidelines }\end{array}$ \\
\hline
\end{tabular}




\begin{tabular}{|c|c|}
\hline $\begin{array}{l}\text { Ongoing Supervision } \\
\text { ICP11-Market Analysis } \\
\text { ICP12-Reporting to supervisors and off-site } \\
\text { monitoring } \\
\text { ICP13 - On-site inspection } \\
\text { ICP14-Preventive and corrective measures } \\
\text { ICP15-Enforcement or sanctions } \\
\text { ICP16-Winding-up or exit from the market } \\
\text { ICP17- Group-wide supervision }\end{array}$ & $\begin{array}{l}\text { A major weakness in this area relates to the limitations on } \\
\text { the supervisor's ability to impose sanctions. This should } \\
\text { be corrected in new legislation. } \\
\text { SVS and Chile must develop a coordinated approach to } \\
\text { the supervision of financial conglomerates. }\end{array}$ \\
\hline $\begin{array}{l}\text { Prudential Requirements } \\
\text { ICP18-Risk assessment and management } \\
\text { ICP19-Insurance activity } \\
\text { ICP20-Liabilities } \\
\text { ICP21-Investments } \\
\text { ICP22-Derivatives and similar commitments } \\
\text { ICP23-Capital adequacy and solvency }\end{array}$ & $\begin{array}{l}\text { One of the key thrusts of the risk-based approach to } \\
\text { supervision is the promotion of risk management } \\
\text { practices among insurance companies. This will be } \\
\text { emphasized through the new guideline on corporate } \\
\text { governance. At present, company practices in this area } \\
\text { have been less than satisfactory. } \\
\text { Solvency measurement is currently based on a model that } \\
\text { resembles European Union Solvency I. While this has } \\
\text { worked reasonably well, the situation will be improved } \\
\text { with the adoption of a risk-based capital formula. }\end{array}$ \\
\hline $\begin{array}{l}\text { Markets and Consumers } \\
\text { ICP24-Intermediaries } \\
\text { ICP25-Consumer Protection } \\
\text { ICP26-Information, disclosure \& transparency } \\
\text { towards markets } \\
\text { ICP27-Fraud }\end{array}$ & $\begin{array}{l}\text { Communication with consumers and consumer access to } \\
\text { information are excellent. } \\
\text { SVS should perhaps take the initiative to lead the fight } \\
\text { against insurance fraud by either consumers or } \\
\text { intermediaries. }\end{array}$ \\
\hline $\begin{array}{l}A M L / C F T \\
\text { ICP28 - Anti-money-laundering, combating the } \\
\text { financing of terrorism (AML/CFT) }\end{array}$ & \\
\hline
\end{tabular}

\section{Recommended action plan}

57. Amendments to Law 251 governing insurance should be adopted as soon as reasonably possible. This will facilitate the implementation of both risk-based capital and the risk-based approach to supervision. A condition precedent to the launch of risk-based supervision is the strengthening of corporate governance.

58. Draft guideline on corporate governance should be adopted as soon as possible. Companies will have to be given a reasonable period of time for full implementation. However the new approach should be established as the desirable standard for all companies.

59. Guidelines specifying new standards for reserving of general (non-life) insurance business should be distributed for discussion and should be adopted as soon as possible. 
60. Development of risk weights and other factors required to perform the risk-based capital test will have to be completed in the near future in order to provide the opportunity for adoption of RBS. SVS should complete the development work as soon as possible.

61. Efforts should be directed at the establishment of an effective local actuarial association. This organization will require high standards for admission of new members and must play the leading role in setting professional and ethical standards for the performance of its members. It is likely that government, perhaps with leadership from SVS along with academic experts, will have to work with the local institute to develop over time the required level of professionalism. Having regard for the important role to be played by the actuaries in monitoring the adequacy of reserves set aside to fund the long-term liabilities arising under the life annuity business, this problem needs urgent attention.

\section{Authorities' response to the assessment}

62. The authorities provided the following response to the assessment:

- $\quad$ SVS has already published the new standards for reserving of general (non-life) insurance business. This is the NCG N 306 dated April 14, 2011 and can be found on the SVS website at http://www.svs.cl/sitio/legislacion_normativa/normativa.php

- In 2009, SVS hired external consultants to develop the risk-based capital factors. The reports supporting the calculation of these factors were available last year and since then SVS has continued to study these factors for the construction of a standard formula.

- $\quad$ SVS agrees with the need to enhance the relevance of the actuarial profession and it has taken some measures in this direction. The corporate governance and risk management rules that SVS will publish in the near future both will reinforce the role of the actuaries, especially with regards to the insurance risks that the insurers face.

\section{B. Implementation of the IOSCO Objectives and Principles of Securities Regulation}

\section{Information and methodology used for the assessment}

63. The assessment was conducted based on the IOSCO Objectives and Principles of Securities Regulation and the associated methodology adopted in 2003, as updated in 2008. In 2010, IOSCO revised its principles and methodology, adding eight new principles, and the associated methodology is under development. Accordingly, a description of findings concerning these principles is included as an annex to the detailed assessment of principles but no assessment was made of compliance with each principle.

64. This assessment of the Chilean capital markets regulatory structure is based upon fieldwork conducted in March-April 2011. This fieldwork included interviews with SVS 
staff, visits to two of the three Chilean stock exchanges, and meetings with representatives of the brokerage community, corporate issuers, and money management firms, as well as academics. SVS provided a self-assessment of the IOSCO principles and additional documentary information and statistical data. Additional information was collected by a review of applicable laws, SVS regulations, and publicly available information. The timely completion of this assessment was greatly facilitated by the cooperation received from numerous members of the SVS staff.

\section{Institutional and market structure—overview}

65. The law provides SVS with clear legal authority in most, but not all, areas of securities regulation. SVS is authorized to regulate the issuance of securities; mandate initial and periodic corporate disclosure; and require registration and continuing oversight of securities markets and market intermediaries, including broker dealers, mutual funds, and mutual fund operators. Broker dealers and mutual fund operators that are fully-owned subsidiaries of banks must be separately incorporated and licensed by SVS. While banks may underwrite securities offerings directly and trade debt securities, they may not engage in equity trading or service retail accounts other than through an SVS-licensed broker dealer subsidiary. While these functions must comply with the requirements of the securities law and applicable SVS regulations, responsibility for enforcing compliance is assigned to SBIF, not SVS. Pension funds are also separately regulated by SP. Investment advisers (except advisers of regulated funds) are unregulated.

66. SVS oversees both the securities markets and the insurance industry. Since the 2004 IOSCO assessment its budget and staff resources have grown significantly. Its budget has increased from $\mathrm{Ch} \$ 5.8$ billion (approximately US\$ 15 million) to $\mathrm{Ch} \$ 11.6$ billion (approximately US\$ 45 million) and the size of its staff has increased from 267 to 313 (total including insurance). The Superintendent has full discretion to control the allocation of resources within the SVS.

67. The SBIF has comprehensive regulatory authority over Chilean banks, including their securities activities. Banks are prohibited from engaging in equity trading for their own account or for clients unless they create a separate registered brokerage subsidiary, subject to SVS oversight. Banks may engage in all other securities activities, including government and corporate debt, where they are significant market participants. SBIF is authorized to enforce the applicable provisions of the securities law when they apply to banks. This includes bank secondary market trading and disclosure obligations of banks.

68. Legislation provides SVS with clear legal authority in most, but not all, areas that a securities regulatory agency requires. It is authorized to regulate the issuance of securities, mandate initial and periodic corporate disclosure, and require registration and continuing oversight of securities markets and market intermediaries, including broker-dealers and mutual funds and mutual fund operators. Broker-dealers and mutual fund operators that are 
fully-owned subsidiaries of banks must be separately incorporated and licensed by SVS. While banks may underwrite securities offerings directly and trade debt securities, they may not engage in equity trading or service retail accounts other than through an SVS-licensed broker-dealer subsidiary. While these functions must comply with the requirements of the securities law and applicable SVS regulations, responsibility for enforcing compliance is assigned to SBIF, not SVS. ${ }^{22}$ Pension funds are also separately regulated by SP; investment advisors (except advisors of regulated funds) are unregulated.

69. There are three securities exchanges in Chile. The Bolsa de Comercio de Santiago is the largest exchange, with approximately 80 percent of trading volume. The Bolsa Electrónica is the second largest exchange with slightly less than 20 percent of trading volume. The Bolsa de Valparaiso is the oldest and smallest exchange. All three exchanges trade the same equity securities, corporate and government debt securities, and a small amount of currency derivatives. The over-the-counter (OTC) bank network dominates currency derivatives and also trades debt securities OTC.

70. There are 270 publicly traded companies in Chile. Public companies are traded simultaneously on all three exchanges. All companies with 500 or more shareholders and all companies with at least 10 percent of shares owned by 100 shareholders must be publicly listed. As of December 2010, total market capitalization of equity shares was US\$ 341.5 billion. The average daily trading amount is US\$ 190 million. Because of its limited free float and general illiquidity, average turnover ratio for all listed equities was only about 18 percent in 2010. Even the most liquid shares are not widely traded. Five of the ten largest companies had turnover ratios in 2010 under 10 percent.

71. The Chilean corporate debt market has grown steadily in the past decade, reaching a peak in 2009 of 70 issues for a total of US\$ 7 billion. This is more than double the amount issued in 2004. Virtually all of the corporate debt is investment grade issued in inflationindexed UF denominations. The AFPs and insurance companies purchase over 80 percent of corporate debt issues and tend to hold to maturity. Nonetheless, the increase in size of the corporate fixed-income market has also been accompanied by an increase in annual turnover rate, which has grown from less than 10 percent in 2004 to just under 60 percent in 2010 .

72. Chile has two categories of broker, corredoras de bolsa and agente de valores. There are 44 corredoras (13 owned by banks) and 16 agentes (five owned by banks). A corredora performs the full range of brokerage services in Chile and must be a member of one of the three exchanges. Five corredoras account for approximately 55 percent of equity trading and over 80 percent of nonbank fixed income trading. The 16 agentes may not trade equity on an exchange and must execute these trades through the facilities of a corredora. In Chile

\footnotetext{
${ }^{22}$ This can result in different regulatory approaches. For example, SBIF focuses on bank disclosure reports primarily with regard to safety and soundness issues, with less emphasis on shareholder investment.
} 
intermediaries are largely engaged in brokerage for their clients; most do not engage in proprietary trading, except in fixed-income.

73. The mutual fund industry in Chile is small but growing. There are 19 registered fund administrators, of which 11 are bank affiliates. They operate 471 mutual funds, with total assets under management of approximately US\$ 33 billion. While this is a small amount in comparison to pension funds, it is a significant increase from the US\$ 8.4 billion under management in 2004. The number of investors has increased comparably, from around 400,000 in 2004 to 1.5 million in 2010. Mutual fund assets are primarily invested in fixedincome securities, of which nearly 50 percent is invested in money market funds.

\section{Preconditions for effective securities regulation}

74. The effectiveness of any system of securities regulation is heavily dependent upon the existence of a strong, independent and efficient judicial system. A securities regulator's enforcement program is only a credible deterrent if the judiciary will act decisively and swiftly. In Chile, judicial delay is a serious problem. Judicial proceedings and appellate review may continue for as long as ten years. Delays of this length vitiate the deterrent effect

of the action taken. For example, SVS reports that three criminal cases were filed in 2008 and 2009 and all of them are still in litigation.

\section{Summary, key findings, and recommendations}

75. Securities market regulation has strengthened significantly since the 2004 FSAP. Further improvement will require significant augmentation of the authority and powers of the SVS in critical areas of broker regulation and in its ability to investigate and enforce compliance with the law. For example, SVS does not have legal authority to compel testimony or documents from persons not subject to its regulation. As such, it may not compel testimony or require the production of documents from investors who are not affiliated with a registered entity, from investment advisers or consultants (who are not regulated under Chilean law), from banks or bank employees (unless they work for a bank subsidiary that is directly regulated by the SVS), or from third parties who may have information relevant to an investigation (such as telephone or email records from a telephone company or internet service provider).

76. Several important recommendations in the 2004 assessment have been implemented. A central counterparty (CCLV) has been created with legal authority of novation, and with the authority to create a central guaranty fund, based upon market participant exposures. Brokers, mutual funds, insurance companies, and pension plans are now required to use the central securities depository as the third-party custodian of securities and with segregation of customer and entity securities in separate accounts. The SVS has grown in staff and made important changes in internal procedures to improve staff accountability, its regulatory transparency, and the appearance of fairness in its sanctions process. The Bolsa de Comercio de Santiago and the Bolsa Electrónica have improved their regulatory and disciplinary 
programs. The adoption and mandatory use of a third-party pricing system by mutual funds and pension funds is a noteworthy accomplishment. Chile has adopted IFRS and has made changes in its definition of auditor independence.

77. Other important recommendations in the 2004 assessment have not been implemented. While banks, brokers, mutual funds, insurance companies and pension funds (and unregulated investment advisers) offer comparable products and services, they are not subject to uniform regulation. Adoption of an industry-wide customer suitability requirement and mandatory internal controls programs for all types of intermediaries should be priorities. The SVS should also utilize its existing powers to improve its system of business conduct regulation so that it is robust and uniform across all sectors of the financial services industry.

78. The Chilean capital markets have grown substantially since the 2004 FSAP. The challenge for SVS is to examine and refine its procedures so that its regulatory processes conform to the changes in the market it regulates. In particular, SVS should make every effort to improve the speed of its enforcement program. Market credibility requires prompt and decisive action. Similarly, the SVS should examine its procedures for reviewing routine fixed-income securities registrations.

\section{Table 5. Chile: Summary Implementation of the IOSCO Principles}

\begin{tabular}{|l|l|}
\hline Principle & Findings \\
\hline $\begin{array}{l}\text { Principle 1. The responsibilities of the regulator } \\
\text { should be clearly and objectively stated }\end{array}$ & $\begin{array}{l}\text { The law provides SVS with clear legal authority in most, but } \\
\text { not all, areas required, as noted in Principle 3. SBIF enforces } \\
\text { compliance by banks. }\end{array}$ \\
\hline $\begin{array}{l}\text { Principle 2. The regulator should be operationally } \\
\text { independent and accountable in the exercise of its } \\
\text { functions and powers }\end{array}$ & $\begin{array}{l}\text { The Superintendent serves at the discretion of the President } \\
\text { and may be removed for any reason. The staff lack legal } \\
\text { protection in the performance of official duties. }\end{array}$ \\
\hline $\begin{array}{l}\text { Principle 3. The regulator should have adequate } \\
\text { powers, proper resources and the capacity to } \\
\text { perform its functions and exercise its powers }\end{array}$ & $\begin{array}{l}\text { SVS lacks necessary authority in several core areas, including } \\
\text { the regulation of investment advisers, authority over failing } \\
\text { brokers, and full investigative authority. }\end{array}$ \\
\hline $\begin{array}{l}\text { Principle 4. The regulator should adopt clear and } \\
\text { consistent regulatory processes }\end{array}$ & $\begin{array}{l}\text { SVS has made several important changes to increase the } \\
\text { transparency and fairness of its processes. Public comment is } \\
\text { now a part of the rulemaking process. }\end{array}$ \\
\hline $\begin{array}{l}\text { Principle 5. The staff of the regulator should } \\
\text { observe the highest professional standards }\end{array}$ & $\begin{array}{l}\text { SVS has adopted a code of conduct and it requires employees } \\
\text { to report all securities transactions. }\end{array}$ \\
\hline $\begin{array}{l}\text { Principle 6 The regulatory regime should make } \\
\text { appropriate use of self-regulatory organizations } \\
\text { (SROs) that exercise some direct oversight } \\
\text { responsibility for their respective areas of } \\
\text { competence and to the extent appropriate to the } \\
\text { size and complexity of the markets }\end{array}$ & $\begin{array}{l}\text { The three stock exchanges in Chile are required to perform } \\
\text { self-regulatory functions. }\end{array}$ \\
\hline
\end{tabular}




\begin{tabular}{|c|c|}
\hline $\begin{array}{l}\text { Principle } 7 \text {. SROs should be subject to the } \\
\text { oversight of the regulator and should observe } \\
\text { standards of fairness and confidentiality when } \\
\text { exercising powers and delegated responsibilities }\end{array}$ & $\begin{array}{l}\text { SVS has full authority to oversee the stock exchanges. In } \\
\text { addition to prior review of all exchange rules, SVS can and } \\
\text { does inspect the exchanges, monitors trading, and can } \\
\text { investigate and sanction them for misconduct. SVS also has } \\
\text { the authority to restrict exchange activities, and suspend or } \\
\text { terminate an exchange license. In the event of liquidation, the } \\
\text { SVS may take control or appoint someone to oversee the } \\
\text { winding down. The Self-Regulation Committee of the two } \\
\text { largest exchanges is an important innovation. }\end{array}$ \\
\hline $\begin{array}{l}\text { Principle } 8 \text {. The regulator should have } \\
\text { comprehensive inspection, investigation and } \\
\text { surveillance powers }\end{array}$ & SVS has comprehensive authority over regulated entities. \\
\hline $\begin{array}{l}\text { Principle } 9 \text {. The regulator should have } \\
\text { comprehensive enforcement powers }\end{array}$ & $\begin{array}{l}\text { SVS lacks comprehensive authority to investigate violations } \\
\text { by persons not under its direct authority. For example, it does } \\
\text { not have legal authority to compel testimony or documents } \\
\text { from persons not subject to its regulation and may not compel } \\
\text { persons to produce bank records or obtain individual AML } \\
\text { transaction reports from the relevant authority. Obtaining } \\
\text { necessary legal authority, which SVS is seeking, should be a } \\
\text { high priority. }\end{array}$ \\
\hline $\begin{array}{l}\text { Principle } 10 . \text { The regulatory system should ensure } \\
\text { an effective and credible use of inspection, } \\
\text { investigation, surveillance and enforcement } \\
\text { powers and implementation of an effective } \\
\text { compliance program. }\end{array}$ & $\begin{array}{l}\text { SVS has continued to upgrade its inspection and enforcement } \\
\text { programs. The lack of a comprehensive internal controls } \\
\text { program for brokers is a significant deficiency-regulated } \\
\text { entities should be required to have in place supervisory and } \\
\text { compliance procedures reasonably designed to prevent } \\
\text { securities law violations. While mutual funds are required to } \\
\text { have systems of internal control to monitor regulatory } \\
\text { compliance, brokers are not, except for AML compliance. }\end{array}$ \\
\hline $\begin{array}{l}\text { Principle } 11 \text { The regulator should have the } \\
\text { authority to share both public and non-public } \\
\text { information with domestic and foreign } \\
\text { counterparts }\end{array}$ & $\begin{array}{l}\text { Legal changes provided SVS with the authority to exchange } \\
\text { information it possesses with domestic and foreign regulators. } \\
\text { As explained in Principle 13, bank secrecy law prevents SVS } \\
\text { from obtaining types of information. }\end{array}$ \\
\hline $\begin{array}{l}\text { Principle 12. Regulators should establish } \\
\text { information sharing mechanisms that set out when } \\
\text { and how they will share both public and } \\
\text { non-public information with their domestic and } \\
\text { foreign counterparts }\end{array}$ & $\begin{array}{l}\text { SVS has signed } 26 \text { MoUs with foreign regulators and is an } \\
\text { Annex B signatory to the IOSCO multilateral MoU. } \\
\text { Completion of the information sharing agreement with SBIF } \\
\text { and SP should be a priority. }\end{array}$ \\
\hline $\begin{array}{l}\text { Principle } 13 \text {. The regulatory system should allow } \\
\text { for assistance to be provided to foreign regulators } \\
\text { who need to make inquiries in the discharge of } \\
\text { their functions and exercise of their powers }\end{array}$ & $\begin{array}{l}\text { SVS requires access to bank secrecy data to meet } \\
\text { international standards for information exchange. }\end{array}$ \\
\hline
\end{tabular}




\begin{tabular}{|c|c|}
\hline $\begin{array}{l}\text { Principle } 14 \text {. There should be full, timely and } \\
\text { accurate disclosure of financial results and other } \\
\text { information that is material to investors' decisions }\end{array}$ & $\begin{array}{l}\text { SVS has a sound issuer disclosure regime. Chilean law } \\
\text { requires all issuers to file a registration statement for SVS } \\
\text { review prior to offering the securities. The registration } \\
\text { statement must contain information on the issuer and its } \\
\text { business plan, two years of audited financial statements, a } \\
\text { description of the issuer's business, information about } \\
\text { directors and management, the identity of the twelve largest } \\
\text { shareholders, and any additional material information. While } \\
\text { two years of audited financial statements are required in the } \\
\text { registration statement, the prospectus provided to investors } \\
\text { contains a shortened summary financial statement }\end{array}$ \\
\hline $\begin{array}{l}\text { Principle } 15 \text {. Holders of securities in a company } \\
\text { should be treated in a fair and equitable manner }\end{array}$ & $\begin{array}{l}\text { The tender offer law provides broad protection for investors } \\
\text { in tender offers and other acquisitions. }\end{array}$ \\
\hline $\begin{array}{l}\text { Principle } 16 \text {. Accounting and auditing standards } \\
\text { should be of a high and internationally acceptable } \\
\text { quality }\end{array}$ & $\begin{array}{l}\text { Chile has adopted IFRS and is completing a multi-year } \\
\text { transition. SVS should consider the need for a formal } \\
\text { accreditation process for auditors. }\end{array}$ \\
\hline $\begin{array}{l}\text { Principle } 17 \text {. The regulatory system should set } \\
\text { standards for the eligibility and the regulation of } \\
\text { those who wish to market or operate a collective } \\
\text { investment scheme }\end{array}$ & $\begin{array}{l}\text { SVS should establish minimum knowledge and professional } \\
\text { standards for senior fund administrators and managers. In } \\
\text { Chile, mutual funds operate through a general funds } \\
\text { administrator that must be registered with SVS, subject to a } \\
\text { range of eligibility criteria. However, there is no specialized } \\
\text { training or experience in mutual fund operations required, no } \\
\text { qualification examination or process, and there are no } \\
\text { continuing education requirements. }\end{array}$ \\
\hline $\begin{array}{l}\text { Principle } 18 \text {. The regulatory system should } \\
\text { provide for rules governing the legal form and } \\
\text { structure of collective investment schemes and the } \\
\text { segregation and protection of client assets }\end{array}$ & $\begin{array}{l}\text { While mutual funds do not have independent legal status, } \\
\text { there is sufficient clarity of form and protections for investors. } \\
\text { While the law does not require funds to retain a third-party } \\
\text { custodian, it has created a series of regulatory safeguards to } \\
\text { protect fund assets. Funds must maintain a shareholder } \\
\text { registry, updated daily, and all fund assets must be kept at } \\
\text { DCV (except those that cannot be maintained there, such as } \\
\text { foreign securities). While DCV does not serve as a third-party } \\
\text { custodian, each fund must have a separate account at DCV } \\
\text { and assets must be held in the name of the specific fund. Each } \\
\text { fund administrator is also required to maintain a separate } \\
\text { guarantee account for each fund for the benefit of investors in } \\
\text { that fund. A bank must be designated as the account } \\
\text { beneficiary on behalf of the investor. }\end{array}$ \\
\hline
\end{tabular}




\begin{tabular}{|c|c|}
\hline $\begin{array}{l}\text { Principle 19. Regulation should require disclosure, } \\
\text { as set forth under the principles for issuers, which } \\
\text { is necessary to evaluate the suitability of a } \\
\text { collective investment scheme for a particular } \\
\text { investor and the value of the investor's interest in } \\
\text { the scheme }\end{array}$ & $\begin{array}{l}\text { Chile's system of explicitly defined types of funds enables } \\
\text { investors to compare funds of the same type and determine } \\
\text { which category of investment is suitable. Mutual funds must } \\
\text { file a registration statement with SVS prior to offering fund } \\
\text { shares to the public. In the past, a fund could not start } \\
\text { operations until SVS completed its review. Legal changes in } \\
2010 \text {, to be effective in the near future, will no longer require } \\
\text { SVS pre-review prior to operations. However, if SVS } \\
\text { identifies deficiencies in the filing, it will have the authority } \\
\text { to halt trading in the fund, and if required, direct the fund to } \\
\text { return investor monies. The elimination of SVS pre-review of } \\
\text { mutual fund offering documents is a significant change that } \\
\text { should be monitored carefully. }\end{array}$ \\
\hline $\begin{array}{l}\text { Principle } 20 \text {. Regulation should ensure that there is } \\
\text { a proper and disclosed basis for assets valuation } \\
\text { and the pricing and the redemption of units in a } \\
\text { collective investment scheme }\end{array}$ & $\begin{array}{l}\text { Development of a uniform pricing model and daily pricing list } \\
\text { for debt securities is an important improvement. }\end{array}$ \\
\hline $\begin{array}{l}\text { Principle 21. Regulation should provide for } \\
\text { minimum entry standards for market } \\
\text { intermediaries }\end{array}$ & $\begin{array}{l}\text { The inability of SVS to consider internal controls and } \\
\text { operating procedures as well as the professional qualification } \\
\text { of key employees in licensing decisions are important } \\
\text { deficiencies. The lack of investment adviser authority is a } \\
\text { third factor in the assessment. }\end{array}$ \\
\hline $\begin{array}{l}\text { Principle } 22 \text {. There should be initial and ongoing } \\
\text { capital and other prudential requirements for } \\
\text { market intermediaries that reflect the risks that the } \\
\text { intermediaries undertake }\end{array}$ & $\begin{array}{l}\text { SVS has a sound capital adequacy program for licensed } \\
\text { brokers. }\end{array}$ \\
\hline $\begin{array}{l}\text { Principle } 23 . \text { Market intermediaries should be } \\
\text { required to comply with standards for internal } \\
\text { organization and operational conduct that aim to } \\
\text { protect the interests of clients, ensure proper } \\
\text { management of risk, and under which management } \\
\text { of the intermediary accepts primary responsibility } \\
\text { for these matters }\end{array}$ & $\begin{array}{l}\text { This is another principle that requires brokers to have sound } \\
\text { and workable internal control processes. SVS should have } \\
\text { client suitability requirement for intermediaries. The law } \\
\text { requires firms to adopt procedures to ensure the segregation } \\
\text { of customer securities with DCV, and a } 2009 \text { SVS circular } \\
\text { establishes internal control requirements for custody of client } \\
\text { assets. SVS created in } 2009 \text { an office responsible for } \\
\text { reviewing customer complaints. This office does not have the } \\
\text { authority to mediate or arbitrate disputes. Intermediaries are } \\
\text { not required to have a mechanism for resolution of investor } \\
\text { complaints. }\end{array}$ \\
\hline $\begin{array}{l}\text { Principle } 24 \text {. There should be a procedure for } \\
\text { dealing with the failure of a market intermediary } \\
\text { in order to minimize damage and loss to investors } \\
\text { and to contain systemic risk }\end{array}$ & $\begin{array}{l}\text { SVS lacks the authority to take some form of action in the } \\
\text { event that an intermediary firm fails. It cannot appoint, or } \\
\text { request a court or other body to appoint, a third-party receiver } \\
\text { or conservator to assume control of a failing firm and oversee } \\
\text { an orderly winding down of operations and the transfer of } \\
\text { client accounts. }\end{array}$ \\
\hline
\end{tabular}




\begin{tabular}{|c|c|}
\hline $\begin{array}{l}\text { Principle } 25 \text {. The establishment of trading systems } \\
\text { including securities exchanges should be subject to } \\
\text { regulatory authorization and oversight }\end{array}$ & $\begin{array}{l}\text { SVS has broad authority to license and monitor exchanges. } \\
\text { There has been major improvement since } 2004 \text { in the } \\
\text { implementation of this principle. The securities law requires } \\
\text { stock exchanges to register with SVS, and to regulate trading } \\
\text { activity and its member firms to ensure a - } \rightarrow \text { fir, competitive, } \\
\text { orderly, and transparent market." Exchanges must } \\
\text { demonstrate the capacity to function effectively, to have } \\
\text { internal governing regulations, and the ability to enforce these } \\
\text { laws. SVS has broad powers to oversee the activities of an } \\
\text { exchange. It has the authority to review all exchange rules, } \\
\text { new products, and new systems of operation. }\end{array}$ \\
\hline $\begin{array}{l}\text { Principle } 26 \text {. There should be ongoing regulatory } \\
\text { supervision of exchanges and trading systems, } \\
\text { which should aim to ensure that the integrity of } \\
\text { trading is maintained through fair and equitable } \\
\text { rules that strike an appropriate balance between } \\
\text { the demands of different market participants }\end{array}$ & $\begin{array}{l}\text { Chilean law clearly provides SVS with full regulatory } \\
\text { authority over Chilean exchanges. SVS reviews all proposed } \\
\text { changes in exchange products, rules, and services, and has } \\
\text { developed an ongoing supervisory inspection process for the } \\
\text { exchanges. }\end{array}$ \\
\hline $\begin{array}{l}\text { Principle } 27 \text {. Regulation should promote } \\
\text { transparency of trading }\end{array}$ & $\begin{array}{l}\text { Better transparency in the OTC debt market is needed. } \\
\text { Because debt trading by banks is only available to the } \\
\text { participating banks, nonbank institutional investors may not } \\
\text { obtain a complete picture of the Chilean debt market. While } \\
\text { institutional investors are able to compare trading on the } \\
\text { markets by requesting quotes from a bank, this is not optimal. } \\
\text { The disparity in transparency and access between exchange } \\
\text { trading and OTC trading should be studied carefully. }\end{array}$ \\
\hline $\begin{array}{l}\text { Principle 28. Regulation should be designed to } \\
\text { detect and deter manipulation and other unfair } \\
\text { trading practices }\end{array}$ & $\begin{array}{l}\text { The law provides SVS with broad legal authority, but limits } \\
\text { on the ability to investigate affects its enforcement capacity. }\end{array}$ \\
\hline $\begin{array}{l}\text { Principle 29. Regulation should aim to ensure the } \\
\text { proper management of large exposures, default } \\
\text { risk and market disruption }\end{array}$ & $\begin{array}{l}\text { Given high concentration and lack of consolidated } \\
\text { supervision, issues of excessive concentration within the } \\
\text { related entities need to be addressed. SVS (and the stock } \\
\text { exchanges) does not have the capacity to monitor targe } \\
\text { exposures" in real time. However, it may obtain information } \\
\text { about the beneficial owners of large positions directly from } \\
\text { the brokerage firm that is trading. With the development of } \\
\text { CCLV as a central counterparty that engages in real-time risk } \\
\text { management of member firms, in the future it may be possible } \\
\text { for SVS to increase its monitoring capability. }\end{array}$ \\
\hline $\begin{array}{l}\text { Principle } 30 \text {. Systems for clearing and settlement } \\
\text { of securities transactions should be subject to } \\
\text { regulatory oversight, and designed to ensure that } \\
\text { they are fair, effective and efficient and that they } \\
\text { reduce systemic risk }\end{array}$ & $\begin{array}{l}\text { The legal changes creating the CCVL and mandating that } \\
\text { brokers, mutual funds, insurance companies and pension } \\
\text { funds establish segregated customer accounts at the DCV are } \\
\text { substantial improvements }\end{array}$ \\
\hline
\end{tabular}




\section{Table 6. Chile: Recommended Action Plan to Improve IOSCO Implementation}

\begin{tabular}{|c|c|}
\hline Reference Principle & Recommended Action \\
\hline $\begin{array}{l}\text { Principles Relating to the } \\
\text { Regulator (P 1-5) }\end{array}$ & $\begin{array}{l}\text { The Superintendent should be appointed for a fixed term, with removal for } \\
\text { good cause. SVS staff should have legal immunity in the performance of } \\
\text { official duties. SVS requires expanded authority in several core areas } \\
\text { described below. SBIF authority to enforce the securities market law should be } \\
\text { consistent with SVS enforcement. }\end{array}$ \\
\hline $\begin{array}{l}\text { Principles of Self-Regulation (P 6- } \\
\text { 7) }\end{array}$ & $\begin{array}{l}\text { The Self-Regulation Committee should have the authority to issue binding } \\
\text { decisions when it considers customer-broker disputes. The bolsas should } \\
\text { adopt rules imposing a customer suitability requirement on its members if } \\
\text { SVS cannot adopt such a rule. }\end{array}$ \\
\hline $\begin{array}{l}\text { Principles for the Enforcement of } \\
\text { Securities Regulation (P 8-10) }\end{array}$ & $\begin{array}{l}\text { SVS should be provided with comprehensive authority to investigate } \\
\text { violations and impose sanctions for any persons who violate the securities law. } \\
\text { It should be exempt from the bank secrecy law when information is necessary } \\
\text { to investigate and enforce compliance. SVS should require all intermediaries } \\
\text { subject to its authority to develop comprehensive internal control programs. }\end{array}$ \\
\hline $\begin{array}{l}\text { Principles for Cooperation in } \\
\text { Regulation (P 11-13) }\end{array}$ & $\begin{array}{l}\text { The information sharing agreement among regulators should be completed as } \\
\text { soon as possible. Coordinated examinations of affiliated entities should be } \\
\text { pursued. Legal reform to permit regulators to obtain banking records is a } \\
\text { priority. }\end{array}$ \\
\hline Principles for Issuers (P 14-16) & Industry development of auditor qualification standards should be supported. \\
\hline $\begin{array}{l}\text { Principles for Collective } \\
\text { Investment Schemes (P 17-20) }\end{array}$ & $\begin{array}{l}\text { SVS should establish minimum knowledge and professional standards for } \\
\text { senior fund administrators and managers. The elimination of SVS pre-review } \\
\text { of mutual fund offering documents is a significant change that should be } \\
\text { monitored carefully. }\end{array}$ \\
\hline $\begin{array}{l}\text { Principles for Market } \\
\text { Intermediaries (P 21-24) }\end{array}$ & $\begin{array}{l}\text { SVS should mandate an industry-wide client suitability requirement and } \\
\text { require that registered intermediaries have a comprehensive system of internal } \\
\text { controls. Rapid implementation of a robust broker employee qualification } \\
\text { program by the self-regulatory organizations is important. SVS should have } \\
\text { the authority to intervene and assume control of a broker that is failing or have } \\
\text { the authority to appoint a third party or seek judicial appointment of a third } \\
\text { party to protect client assets and ensure an orderly termination of activities. }\end{array}$ \\
\hline $\begin{array}{l}\text { Principles for the Secondary } \\
\text { Market (P 25-30) }\end{array}$ & $\begin{array}{l}\text { OTC debt trading transparency could be improved. SVS should focus attention } \\
\text { on developing systems to closely monitor large market exposures across entire } \\
\text { financial conglomerates. Fully implementing the CCLV and developing a } \\
\text { robust clearing system with a sufficient guaranty fund should be priorities. }\end{array}$ \\
\hline
\end{tabular}

\section{Authorities' response to the assessment}

79. The authorities were in broad agreement with the assessment. 


\section{Table 7. Chile: Selected Economic Indicators}

$\begin{array}{lr}\text { GDP (2010) } & 103,742 \\ \text { U.S. dollars (billions) } & 203.3 \\ \text { Per capita (U.S. dollars) } & 11,981 \\ & \\ \text { Population characteristics (2009) } & 17.0 \\ \quad \text { Total (in millions) } & 88.7 \\ \text { Urban population (percent of total) } & 78.7 \\ \text { Life expectancy at birth (years) }\end{array}$

I. Social and Demographic Indicators

103,742

17.0

88.7
78.7 $\begin{array}{lr}\text { Poverty rate (2009) } & 15.1\end{array}$

Indigent 3.7

Poor, not indigent $\quad 11.4$

Income distribution (2009)

Richest $10 \%$ of households $\quad 40.2$

Poorest $20 \%$ of households

Gini coefficient $\quad 0.55$

II. Economic Indicators

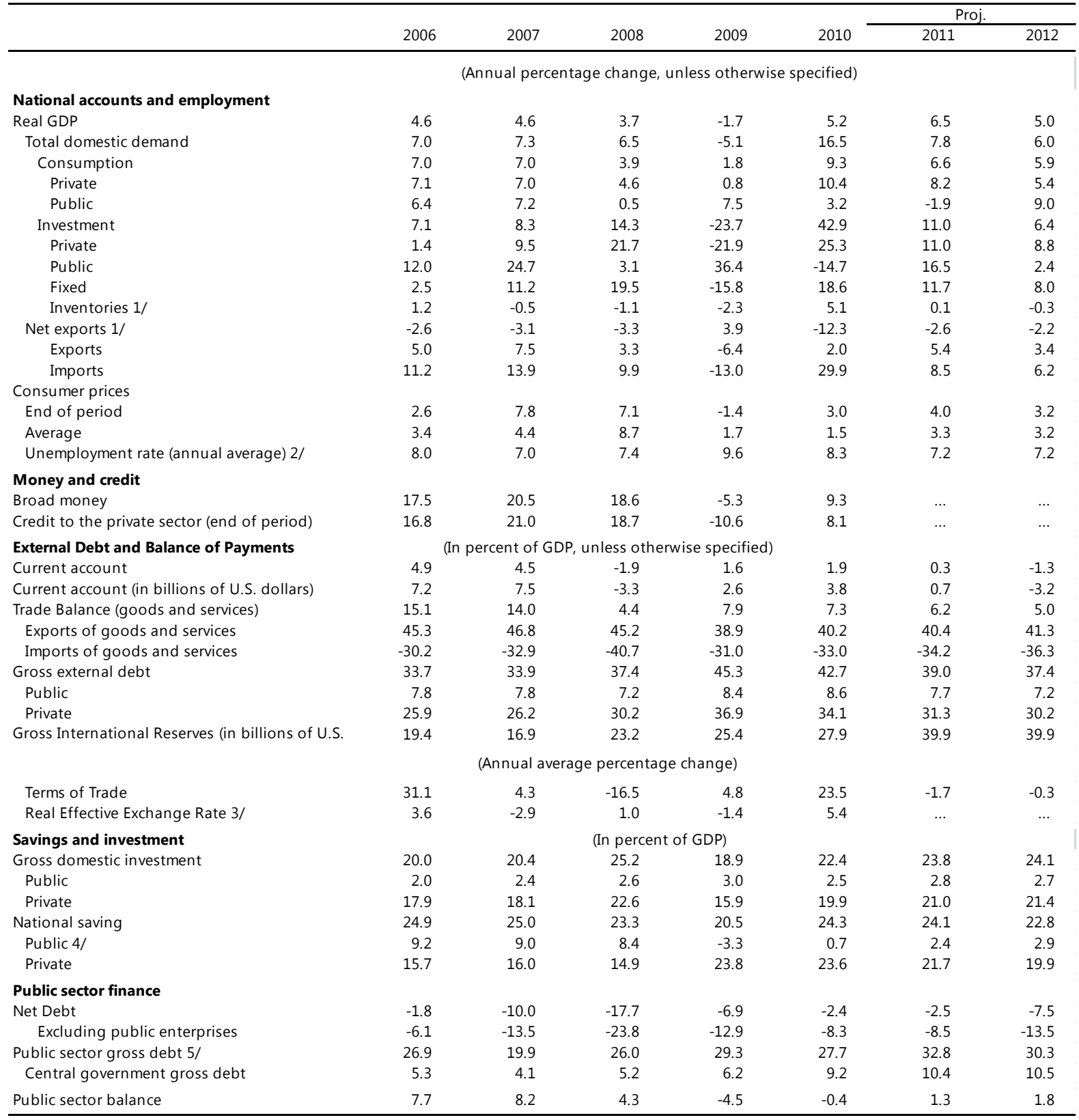

Sources: Central Bank of Chile, Ministry of Finance, Haver Analytics, and Fund staff estimates.

$1 /$ Contribution to growth.

2/ The methodology to compute the unemployment rate changed in 2009.

3/ INS REER. A positive change implies a real appreciation; a negative change implies a real depreciation.

4/ Gross saving of the general government sector, including the deficit of the central bank.

5/ Gross consolidated debt of the public sector (central bank, non-financial public enterprises, and general government). 
Table 8. Chile: Financial System Structure

\begin{tabular}{|c|c|c|c|c|c|c|}
\hline & \multicolumn{3}{|c|}{2005} & \multicolumn{3}{|c|}{2010} \\
\hline & $\begin{array}{l}\text { Number of } \\
\text { institutions }\end{array}$ & $\begin{array}{c}\text { Assets } \\
\text { (\% Total) }\end{array}$ & $\begin{array}{c}\text { Assets } \\
(\% \text { GDP) }\end{array}$ & $\begin{array}{l}\text { Number of } \\
\text { institutions }\end{array}$ & $\begin{array}{c}\text { Assets } \\
\text { (\% Total) }\end{array}$ & $\begin{array}{c}\text { Assets } \\
(\% \text { GDP) } \\
\end{array}$ \\
\hline Banks & 26 & 50.5 & 92.7 & 25 & 49.4 & 102.8 \\
\hline Domestic banks & 13 & 22.6 & 41.5 & 11 & 21.7 & 45.2 \\
\hline Foreign banks & 12 & 19.2 & 35.2 & 13 & 19.1 & 39.7 \\
\hline Subsidiaries & 6 & 16.5 & 30.3 & 8 & 18.8 & 39.1 \\
\hline Branches & 6 & 2.7 & 4.9 & 5 & 0.3 & 0.7 \\
\hline State-owned & 1 & 8.7 & 16.0 & 1 & 8.6 & 17.9 \\
\hline Insurance companies 1/ & 51 & 11.0 & 20.1 & 57 & 9.7 & 20.1 \\
\hline Property and casualty & 22 & 0.6 & 1.0 & 26 & 0.8 & 1.6 \\
\hline Life & 29 & 10.4 & 19.1 & 31 & 8.9 & 18.5 \\
\hline Pension fund administrators $1 / 2 /$ & 6 & 31.7 & 58.1 & 6 & 30.6 & 63.7 \\
\hline Other fund administrators $1 / 2 / 3$ / & 43 & 6.9 & 12.6 & 43 & 10.3 & 21.4 \\
\hline Total & 126 & 100.0 & 183.5 & 131 & 100.0 & 208.1 \\
\hline
\end{tabular}

Source: SBIF, SVS, SP and staff calculations.

1/ 2010 figure as of Sep.

2/ Assets under management.

3 / Includes mutual funds, investment funds, investment funds for foreign capital.

\section{Table 9. Chile: Financial Soundness Indicators (in percent) ${ }^{1 /}$}

Financial Soundness Indicators $1 /$

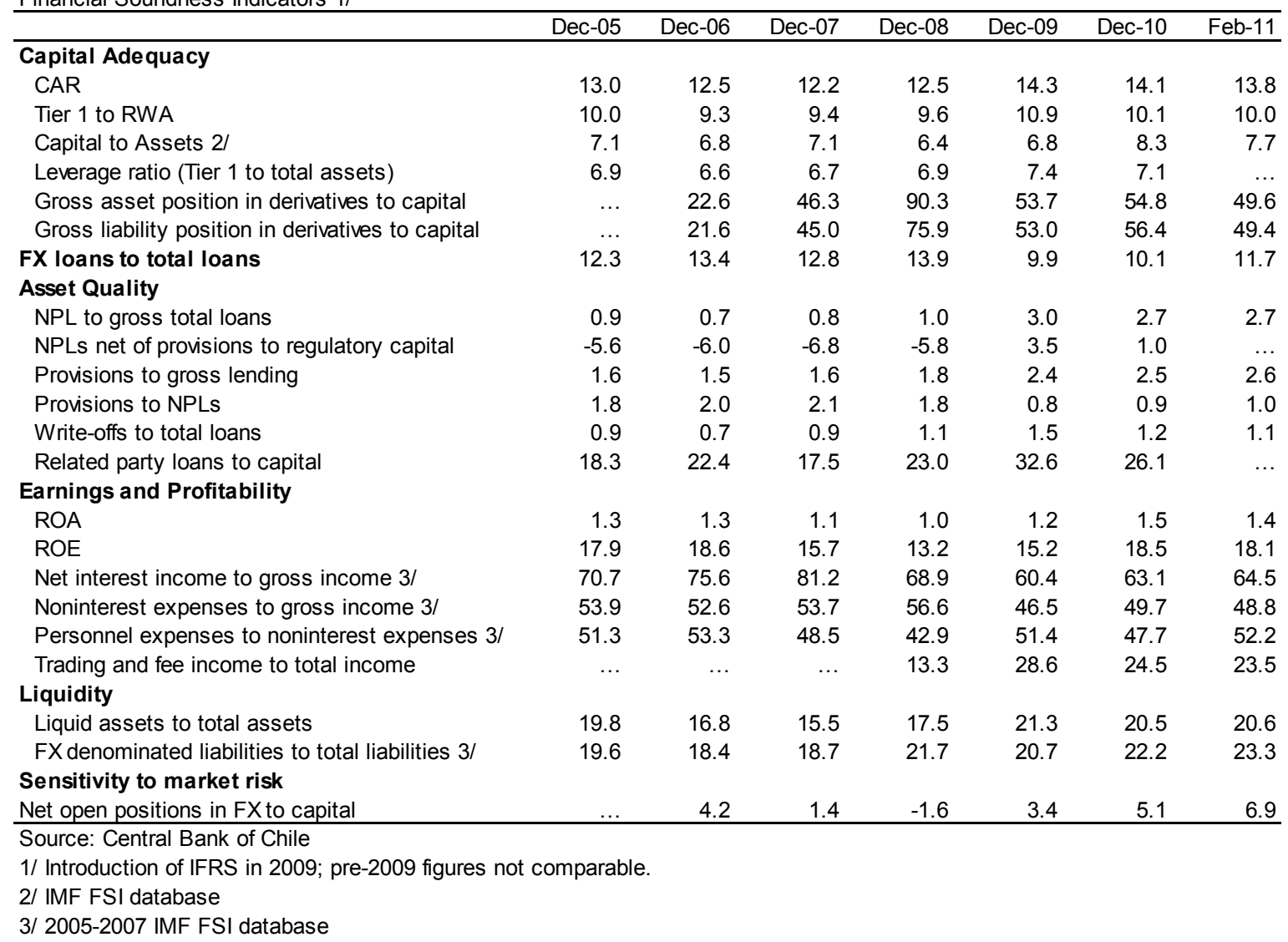




\section{Appendix 1. Chile: Main Recommendations of the 2004 FSAP}

\begin{tabular}{|c|c|}
\hline Main Recommendations & Implementation Status \\
\hline \multicolumn{2}{|r|}{ Central Bank } \\
\hline Strengthen BCCh`s financial accounts & $\begin{array}{l}\text { PARTLY DONE-The } 2006 \text { Fiscal Responsibility Law established a } \\
\text { mechanism for the central government to gradually recapitalize BCCh } \\
\text { in years of fiscal surplus. These transfers stopped in } 2009 \text { when } \\
\text { countercyclical fiscal stimulus moved fiscal balance into deficit. }\end{array}$ \\
\hline \multicolumn{2}{|r|}{ Commercial Banks } \\
\hline $\begin{array}{l}\text { Further develop risk-based supervisory } \\
\text { approach }\end{array}$ & DONE \\
\hline $\begin{array}{l}\text { Clarify SBIF's powers as regards licenses } \\
\text { and expand fit and proper' tests }\end{array}$ & $\begin{array}{l}\text { PARTLY DONE - Fit and proper requirements expanded for } \\
\text { shareholders, but not for directors and managers. }\end{array}$ \\
\hline Impose capital requirements for market risk & DONE_-Limit on market risks consistent with Basel I \\
\hline $\begin{array}{l}\text { Improve disclosure of risk exposure, } \\
\text { management practices by banks }\end{array}$ & DONE \\
\hline Strengthen bank resolution regime & NOT DONE \\
\hline \multicolumn{2}{|r|}{ Corporate Sector } \\
\hline Reform legislation for movable collateral & DONE \\
\hline Create national register of pledges & DONE-National register created in 2007 , but in transition. \\
\hline Improve quality of SME financial statements & NOT DONE—Difficult to address as SMEs are typically unregulated. \\
\hline $\begin{array}{l}\text { Eliminate tasa máxima convencional }{ }^{`} \text { or } \\
\text { introduce more flexibility }\end{array}$ & $\begin{array}{l}\text { NOT DONE-Current focus of the authorities is to introduce more } \\
\text { flexibility, for instance through a less backward-looking rule to } \\
\text { address changes in policy rates. }\end{array}$ \\
\hline \multicolumn{2}{|r|}{ Insurance } \\
\hline $\begin{array}{l}\text { Upgrade provisioning requirements and } \\
\text { strengthen supervision }\end{array}$ & $\begin{array}{l}\text { DONE-Mortality tables for pensions (male and female) updated in } \\
2004 \text { and again in 2010; tables utilized to book the technical } \\
\text { provisions of beneficiaries and disabled persons updated in } 2007 \text {. }\end{array}$ \\
\hline $\begin{array}{l}\text { Strengthen insurance company failure } \\
\text { resolution framework }\end{array}$ & $\begin{array}{l}\text { PARTLY DONE-The law now allows for the transfer of a portfolio } \\
\text { of annuities from one life insurance company to another. It also } \\
\text { allows the SVS to take early actions under certain conditions. } \\
\text { Legislation to be introduced to Congress will provide SVS with } \\
\text { enhanced powers and particularly the authority to intervene at an } \\
\text { earlier date and take remedial action in advance of failure. }\end{array}$ \\
\hline $\begin{array}{l}\text { Shift emphasis from rules management to } \\
\text { risk management }\end{array}$ & $\begin{array}{l}\text { ALMOST DONE-Legislation to be introduced to Congress will } \\
\text { mandate a risk classification system based upon solvency and } \\
\text { supervisor's assessment of riskiness of each company. Rules will } \\
\text { include adoption of a risk-based capital formula. Inspection process } \\
\text { has been developed to implement fully a risk-based approach to } \\
\text { supervision. Over the last four years, all companies have been } \\
\text { subjected to a new inspection process, effectively implementing risk- } \\
\text { based supervision. }\end{array}$ \\
\hline
\end{tabular}




\section{Pension Funds}

Judiciously relax investment regime

PARTLY DONE - Steps taken to relax the regime; further progress is linked to advances in benchmarking and risk management..

Move from compliance-based to risk-based supervision

Encourage outsourcing and regulate service providers

Enhance attractiveness of voluntary system

Develop contingent strategy to enhance competition

Reduce risks faced by workers at retirement



Embed concepts of finality, netting, and novation in the law

Promote industry-financed fund for multilateral netting

Organize securities lending and borrowing

Establish price reporting for OTC trades, harmonize securities valuation

Introduce international standard contract for repos and derivatives

Enhance standardization of financial instruments

Suitably formalize market-makers for public debt

Increase SVS ‘s budgetary and staff resources

Introduce minimum standards for securities industry

Require internal compliance programs by brokerage firms

Widen SVS enforcement powers

Give SVS power to appoint a conservator or liquidator for brokerage firms
DONE

DONE

DONE-Much happened, though results will take time to materialize.

PARTLY DONE - Steps include the recent introduction of an auction system on the fees to charge to contributors.

PARTLY DONE - Steps include the option to purchase annuities after retiring under the programmed withdrawal option, but not before.

\section{Securities Markets}

DONE

DONE - CCLV provides multilateral netting of exchange traded securities

PARTLY DONE-Securities lending facilities exist, however collateral and margining requirements are too high.

NOT DONE

PARTLY DONE - Standard agreement for repos is voluntary, thus benefit of standardization are not certain. No master standard yet for derivatives.

PARTLY DONE — Passage of law amendments needed.

PARTLY DONE — Large brokers are now included but no formal standards.

DONE

PARTLY DONE - 2010 amendments authorize creation of professional qualifications for broker personnel. Mutual fund, bank and pension sales personnel are not covered.

PARTLY DONE - Brokers are required to have AML internal compliance programs. Other aspects not covered.

NOT DONE-Authority to investigate and sanction persons not associated with securities industry required. SVS should have access to bank records, AML reports, and ability to compel full document production.

NOT DONE — Legal authority required. 


\begin{tabular}{|c|c|}
\hline Implement risk based supervision & DONE \\
\hline \multicolumn{2}{|c|}{ Taxation, Financial Reporting Standards, Corporate Governance } \\
\hline Review financial sector taxation & $\begin{array}{l}\text { PARTLY DONE-Differential capital gains tax treatment adversely } \\
\text { affects market liquidity and development of derivatives market }\end{array}$ \\
\hline $\begin{array}{l}\text { Strengthen financial reporting regime for } \\
\text { listed companies }\end{array}$ & $D O N E$ \\
\hline $\begin{array}{l}\text { Enhance corporate governance including } \\
\text { training of directors, judges }\end{array}$ & $\begin{array}{l}\text { PARTLY DONE - Corporate Governance Law of } 2010 \text { made } \\
\text { significant progress. }\end{array}$ \\
\hline \multicolumn{2}{|r|}{ Hedges } \\
\hline $\begin{array}{l}\text { Correct deficiencies in information and } \\
\text { market infrastructure }\end{array}$ & $\begin{array}{l}\text { PARTLY DONE - Creation of CCLV and mandatory custody at DCV } \\
\text { are improvements in market infrastructure. Bilateral transaction in } \\
\text { OTC debt and derivatives markets should be addressed. }\end{array}$ \\
\hline $\begin{array}{l}\text { Relax restrictions on short selling, writing } \\
\text { and trading }\end{array}$ & PARTLY DONE_-Progress ongoing with institutional investors. \\
\hline \multicolumn{2}{|c|}{ Cross-Sectoral Financial Oversight } \\
\hline $\begin{array}{l}\text { Embed Committee of Superintendents in the } \\
\text { law }\end{array}$ & PARTLY DONE \\
\hline $\begin{array}{l}\text { Establish MOUs and technical secretariat for } \\
\text { coordinating committees }\end{array}$ & $\begin{array}{l}D O N E \text {-Secretariat created. Work ongoing to refine it further (MoU } \\
\text { not completed and signed yet). }\end{array}$ \\
\hline Introduce regular staff exchanges & NOT DONE \\
\hline $\begin{array}{l}\text { Introduce fully consolidated supervision and } \\
\text { relax firewalls }\end{array}$ & $\begin{array}{l}\text { NOT DONE_-Law permits exchange of information among } \\
\text { regulators; lack of legal framework prevents full implementation. }\end{array}$ \\
\hline $\begin{array}{l}\text { Resolve conflicts of competence and draw } \\
\text { contingency plans for failure of financial } \\
\text { conglomerates }\end{array}$ & NOT DONE \\
\hline Strengthen the information system & $\begin{array}{l}\text { PARTLY DONE_-Regulators have legal authority to share. MoU } \\
\text { required to implement. }\end{array}$ \\
\hline $\begin{array}{l}\text { Clarify and strengthen legal protection of } \\
\text { supervisors }\end{array}$ & $\begin{array}{l}\text { PARTLY DONE-Superintendent is only SVS person with some } \\
\text { limited protection. }\end{array}$ \\
\hline $\begin{array}{l}\text { Allow supervisors control over budget with } \\
\text { appropriate accountability }\end{array}$ & $\begin{array}{l}\text { NOT DONE - SVS budget determined by ministry of finance and } \\
\text { legislature. }\end{array}$ \\
\hline $\begin{array}{l}\text { Disconnect timing of Superintendents } \\
\text { appointments from political cycle }\end{array}$ & NOT DONE \\
\hline \multicolumn{2}{|r|}{ Anti-Money Laundering } \\
\hline Strengthen capacity to monitor compliance & PARTLY DONE \\
\hline $\begin{array}{l}\text { Enhance monitoring of securities, insurance, } \\
\text { and foreign exchange operators }\end{array}$ & PARTLY DONE \\
\hline $\begin{array}{l}\text { Improve mutual assistance / international } \\
\text { cooperation in freezing assets }\end{array}$ & NOT DONE \\
\hline
\end{tabular}




\section{Appendix II. Chile: Risk Assessment Matrix}

\begin{tabular}{|c|c|c|}
\hline $\begin{array}{l}\text { Nature/Source } \\
\text { of Key Threats }\end{array}$ & $\begin{array}{l}\text { Likelihood of Severe Realization of Threat (in } \\
\text { the next two years) }\end{array}$ & $\begin{array}{c}\text { Expected Impact on Financial Stability if } \\
\text { Threat is Realized }\end{array}$ \\
\hline $\begin{array}{l}\text { Strong capital } \\
\text { inflows }\end{array}$ & $\begin{array}{l}\text { Staff assessment: MEDIUM } \\
\text { Higher growth in Chile and most emerging } \\
\text { markets compared to advanced countries, coupled } \\
\text { with higher interest rates in emerging markets } \\
\text { would continue to attract capital. } \\
\text { Continued capital inflow could lead to asset price } \\
\text { bubbles in short to medium term. However, at } \\
\text { present asset prices are estimated to be close to } \\
\text { their equilibrium level, with the stock market } \\
\text { being just moderately overpriced. }\end{array}$ & $\begin{array}{l}\text { Staff assessment: MEDIUM } \\
\text { Significant overvaluation of key assets and } \\
\text { external funding availability could contribute to an } \\
\text { overheating of the economy through increased } \\
\text { consumer and corporate lending, potentially } \\
\text { resulting in higher credit, foreign exchange, and } \\
\text { liquidity risk of financial institutions. } \\
\text { The impact on banks' books could be magnified } \\
\text { by the high concentration of loans and } \\
\text { conglomerate structures. }\end{array}$ \\
\hline $\begin{array}{l}\text { Slowdown in } \\
\text { economic } \\
\text { growth in the } \\
\text { United States } \\
\text { and } \\
\text { overheating in } \\
\text { Emerging } \\
\text { Asia, } \\
\text { particularly } \\
\text { China }\end{array}$ & $\begin{array}{l}\text { Staff assessment: MEDIUM } \\
\text { Rising inflation in China and other emerging } \\
\text { market countries could prompt monetary policy to } \\
\text { overshoot and trigger a hard landing with severe } \\
\text { consequences on commodity prices and global } \\
\text { demand. } \\
\text { Consumption spending in the U.S. could remain } \\
\text { lower than projected, thus could continue to } \\
\text { depress corporate and small business profits, } \\
\text { hampering GDP growth. }\end{array}$ & $\begin{array}{l}\text { Staff assessment: MEDIUM } \\
\text { Weaker external demand from main trading } \\
\text { partners and lower terms of trade would affect } \\
\text { corporate profits and domestic demand, leading to } \\
\text { higher credit risk and increased chances of an } \\
\text { exchange rate correction, with the attendant } \\
\text { foreign exchange risks. } \\
\text { In case external demand is affected marginally, } \\
\text { some domestic sectors may benefit from the } \\
\text { exchange rate correction. }\end{array}$ \\
\hline $\begin{array}{l}\text { Significant } \\
\text { deterioration } \\
\text { in financial } \\
\text { conditions in } \\
\text { peripheral } \\
\text { Europe }\end{array}$ & $\begin{array}{l}\text { Staff assessment: MEDIUM } \\
\text { Deteriorating financial conditions in peripheral } \\
\text { Europe could result in rising funding costs in } \\
\text { Chile. } \\
\text { (Low direct exposure to Europe would limit the } \\
\text { impact on banks through this channel.) }\end{array}$ & $\begin{array}{l}\text { Staff assessment: } L O W-M E D I U M \\
\text { Domestic banks and corporates could start } \\
\text { experiencing reduced access to external funds and } \\
\text { higher borrowing costs, the peso would likely } \\
\text { depreciate, and domestic activity weakens. } \\
\text { The potential impact on the credit risk of domestic } \\
\text { corporates could remain moderate, despite their } \\
\text { increasing indebtedness, but households could be } \\
\text { more affected. }\end{array}$ \\
\hline $\begin{array}{l}\text { Fast } \\
\text { withdrawal of } \\
\text { banks' } \\
\text { wholesale } \\
\text { deposits }\end{array}$ & $\begin{array}{l}\text { Staff assessment: MEDIUM-HIGH } \\
\text { Changes in valuation rules affecting money market } \\
\text { mutual funds could lead to further reductions in } \\
\text { local bank term wholesale deposits. } \\
\text { With increasing interest rates in advanced } \\
\text { countries, pension funds could quickly move their } \\
\text { wholesale deposits abroad chasing safer returns. }\end{array}$ & $\begin{array}{l}\text { Staff assessment: } L O W-M E D I U M \\
\text { Some banks heavily relying on wholesale funding } \\
\text { could be severely affected by fast wholesale } \\
\text { deposit withdrawal, The potential systemic impact } \\
\text { would not be high due to the small size of these } \\
\text { banks, but disruptions could emerge in the } \\
\text { interbank market and through elevated liquidity } \\
\text { demand. }\end{array}$ \\
\hline
\end{tabular}

